\title{
Rigorously Valuing the Impact of Hurricanes Irma and Maria on Coastal Hazard Risk in Florida and Puerto Rico
}

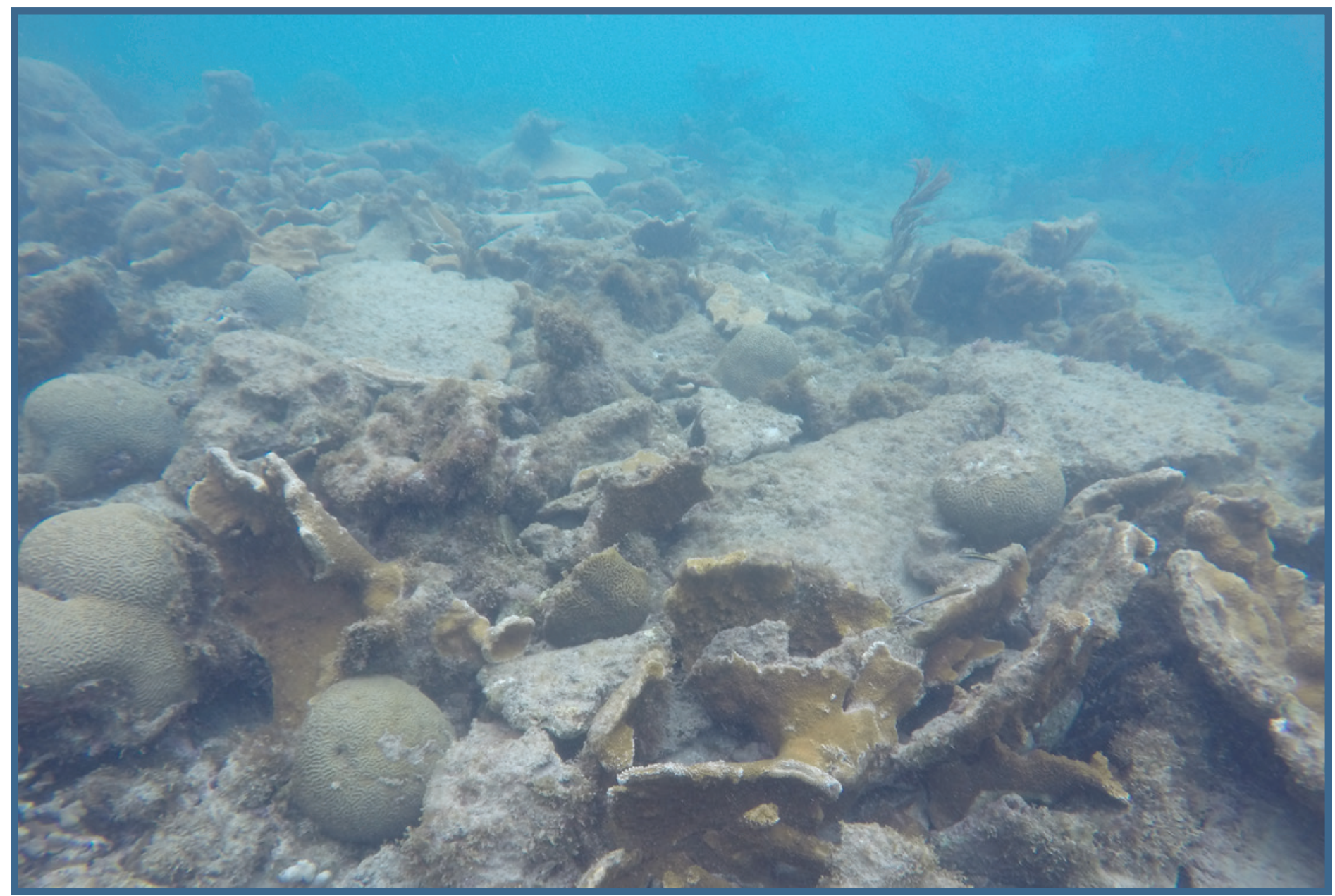

Open-File Report 2021-1056 
Cover. Underwater photograph showing detached and broken coral heads off San Juan, Puerto Rico, following Hurricanes Irma and Maria. Photograph from the National Oceanic and Atmospheric Administration, used with permission. 


\section{Rigorously Valuing the Impact of Hurricanes Irma and Maria on Coastal Hazard Risk in Florida and Puerto Rico}

By Curt D. Storlazzi, Borja G. Reguero, T. Shay Viehman, Kristen A. Cumming, Aaron D. Cole, James B. Shope, Sarah H. Groves, Camila Gaido L., Barry A. Nickel, and Michael W. Beck

Open-File Report 2021-1056 


\section{U.S. Geological Survey, Reston, Virginia: 2021}

For more information on the USGS — the Federal source for science about the Earth, its natural and living resources, natural hazards, and the environment-visit https://www.usgs.gov or call 1-888-ASK-USGS.

For an overview of USGS information products, including maps, imagery, and publications, visit https://store.usgs.gov.

Any use of trade, firm, or product names is for descriptive purposes only and does not imply endorsement by the U.S. Government.

Although this information product, for the most part, is in the public domain, it also may contain copyrighted materials as noted in the text. Permission to reproduce copyrighted items must be secured from the copyright owner.

Suggested citation:

Storlazzi, C.D., Reguero, B.G., Viehman, T.S., Cumming, K.A., Cole, A.D., Shope, J.B., Groves, S.H., Gaido L., C., Nickel, B.A., and Beck, M.W., 2021, Rigorously valuing the impact of Hurricanes Irma and Maria on coastal hazard risks in Florida and Puerto Rico: U.S. Geological Survey Open-File Report 2021-1056, 29 p., https://doi.org/10.3133/ ofr20211056.

Associated data for this publication:

Cumming, K.A., Cole, A.D., Graves, S.H., Storlazzi, C.D., Reguero, B.G., Viehman, T.S., Shope, J.B., and Gaido L., C., Nickel, B.A., and Beck, M.W., 2021, Projected flooding extents and depths based on 10-, 50-, 100-, and 500-year wave-energy return periods for the State of Florida and the Commonwealth of Puerto Rico before and after Hurricanes Irma and Maria due to the storms' damage to the coral reefs: U.S. Geological Survey data release, https:// doi.org/10.5066/P9EHOBKO.

ISSN 2331-1258 (online) 


\section{Contents}

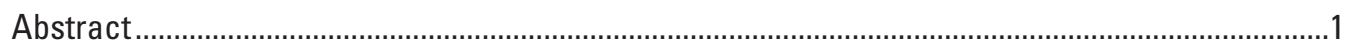

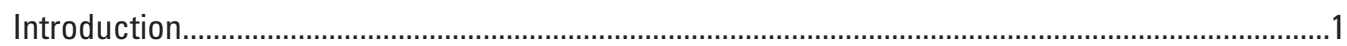

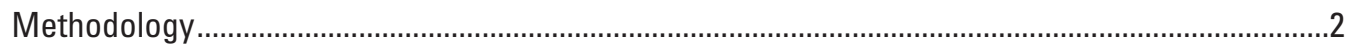

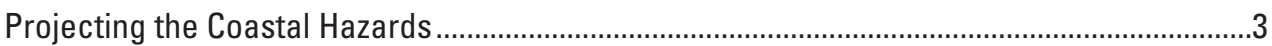

Evaluating the Role of Coral Reefs in Coastal Protection ......................................................6

Evaluating the Role of Hurricane-induced Storm Damage to Coral Reefs in Reducing

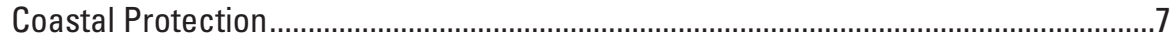

Quantifying the Social and Economic Impact of Coral Reef Damage...................................10

Uncertainties, Limitations, and Assumptions ...........................................................................14

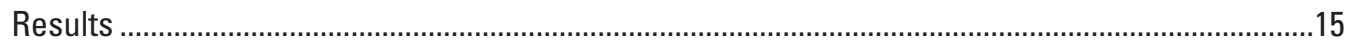

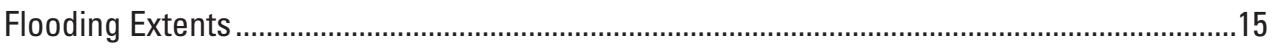

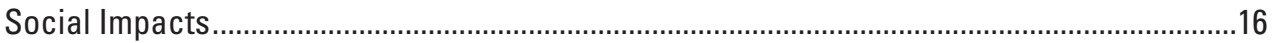

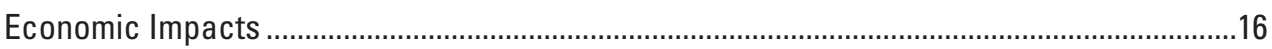

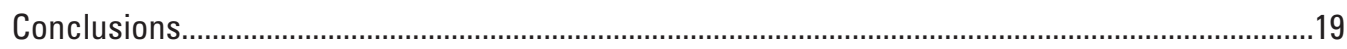

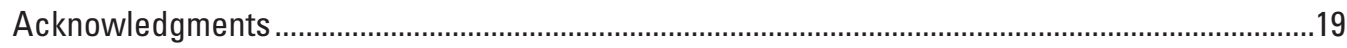

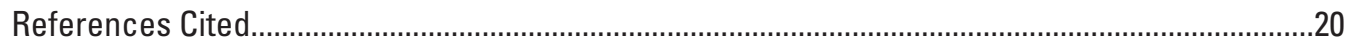

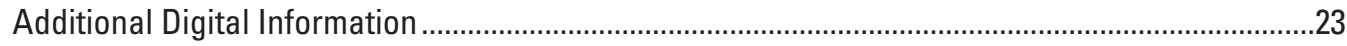

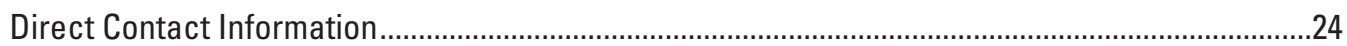

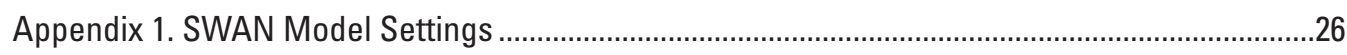

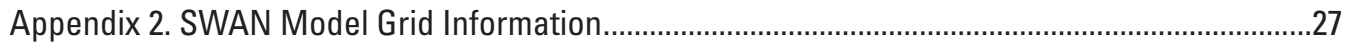

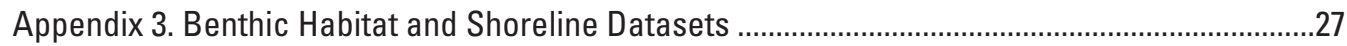

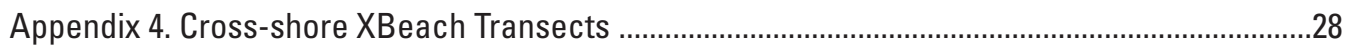

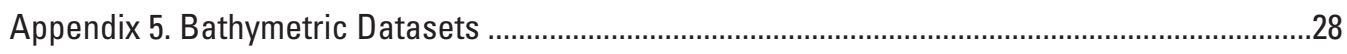

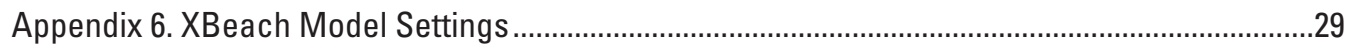

\section{Figures}

1. Map indicating the location of the study areas in Florida and Puerto Rico .......................2

2. Schematic diagram that shows the methodology used to evaluate the increase in coastal flooding hazard risk owing to hurricane-induced damage to coral reefs ...........4

3. Maps showing output examples of the Simulating Waves Nearshore model and how one of the 500 wave conditions was dynamically downscaled to the 200-meter grid scale offshore northeastern Puerto Rico .........................................................................

4. Example map showing the coral extent and coverage and XBeach transects offshore Marathon, Vaca Key, Florida............................................................................6

5. Maps showing example extent and magnitude of damage to the coral reefs caused by the 2017 Hurricanes in Florida and Puerto Rico ............................................................

6. Plots of Puerto Rico example topographic-bathymetric cross-sections and XBeach model wave-driven total water levels during the 100 -year storm before the hurricanes and after the hurricane-induced damage to the coral reefs.

7. Map showing example 100 -year floodplains for pre-storms and post-storms coral reef conditions on eastern San Juan, Puerto Rico .........................................................10

8. Maps showing example 10-meter resolution flood depths for various storm recurrence intervals on Key West, Florida. 
9. Map showing the distribution of people now exposed to coastal flooding because of the hurricane-induced storm damage to the coral reefs for the 100-year storm eastern San Juan, Puerto Rico.

10. Map showing value of infrastructure now exposed to coastal flooding because of hurricane-induced storm damage to the coral reefs for the 100 -year storm eastern San Juan, Puerto Rico

11. Example plots showing damage curves both for pre-storms and post-storms reef conditions for Puerto Rico.

\section{Tables}

1. Wave and current friction coefficients for different percentages of coral cover as determined from benthic habitat maps following Storlazzi and others (2019)

2. Gross domestic product per person by island or region

3. Spatial extent, in square kilometers, of area no longer protected from coastal flooding because of the hurricane-induced damage to coral reefs for different return-interval storms by region

4. Total number of people whom lost protection from coastal flooding because of the hurricane-induced damage to coral reefs for different return-interval storms by region

5. Total number of buildings that lost protection from coastal flooding because of the hurricane-induced damage to coral reefs for different return-interval storms by region

6. Total value of all infrastructure types that lost protection from coastal flooding because of the hurricane-induced damage to coral reefs for different return-interval storms by region

7. Total value of economic activity that lost protection from coastal flooding because of the hurricane-induced damage to coral reefs for different return-interval storms by region.

8. Annual value that lost protection from coastal flooding because of the hurricaneinduced damage to coral reefs by region. 


\section{Conversion Factors}

U.S. customary units to International System of Units

\begin{tabular}{lll}
\hline \multicolumn{1}{c}{ Multiply } & \multicolumn{1}{c}{ By } & \multicolumn{1}{c}{ To obtain } \\
\hline & \multicolumn{1}{c}{ Length } & \\
\hline foot $(\mathrm{ft})$ & 0.3048 & meter $(\mathrm{m})$ \\
mile $(\mathrm{mi})$ & 1.609 & kilometer $(\mathrm{km})$ \\
yard (yd) & 0.9144 & meter $(\mathrm{m})$ \\
\hline \multicolumn{2}{c}{ Area } & \\
\hline square foot $\left(\mathrm{ft}^{2}\right)$ & 0.09290 & square meter $\left(\mathrm{m}^{2}\right)$ \\
square mile $\left(\mathrm{mi}^{2}\right)$ & 2.590 & square kilometer $\left(\mathrm{km}^{2}\right)$ \\
\hline
\end{tabular}

\section{Abbreviations}

$\begin{array}{ll}\text { DSAS } & \text { Digital Shoreline Analysis System } \\ \text { EAB } & \text { Expected Annual Benefit } \\ \text { EAD } & \text { Expected Annual Damage } \\ \text { FEMA } & \text { Federal Emergency Management Agency } \\ \text { GEV } & \text { General Extreme Value } \\ \text { GOW } & \text { Global Ocean Wave } \\ \text { GDP } & \text { Gross Domestic Product } \\ \text { HAZUS } & \text { Federal Emergency Management Agency database } \\ \text { NOAA } & \text { National Oceanic and Atmospheric Administration } \\ \text { PAEK } & \text { Polynomial Approximation with Exponential Kernal } \\ \text { SBC } & \text { Smoothed Baseline Cast } \\ \text { SWAN } & \text { Deltares 2-dimensional short wave model } \\ \text { UCSC } & \text { University of California at Santa Cruz } \\ \text { USACE } & \text { United State Army Corps of Engineers } \\ \text { USGS } & \text { United States Geological Survey } \\ \text { XBeach } & \text { Deltares 2-dimensional short and long wave and flow model }\end{array}$

\section{Variables}

$C_{f} \quad$ Friction coefficient for currents and infragravity wave friction

$f_{w} \quad$ Friction coefficient for incident waves 



\title{
Rigorously Valuing the Impact of Hurricanes Irma and Maria on Coastal Hazard Risk in Florida and Puerto Rico
}

\author{
By Curt D. Storlazzi, ${ }^{1}$ Borja G. Reguero, ${ }^{2}$ T. Shay Viehman, ${ }^{3}$ Kristen A. Cumming, ${ }^{1}$ Aaron D. Cole, ${ }^{2}$ \\ James B. Shope, ${ }^{2}$ Sarah H. Groves, ${ }^{3}$ Camila Gaido L., ${ }^{2}$ Barry A. Nickel, ${ }^{2}$ and Michael W. Beck ${ }^{2}$
}

\section{Abstract}

The degradation of coastal habitats, particularly coral reefs, raises risks by increasing the exposure of coastal communities to flooding hazards. In the United States, the physical protective services provided by coral reefs were recently assessed in social and economic terms, with the annual protection provided by U.S. coral reefs off the coasts of the State of Florida and the Commonwealth of Puerto Rico estimated to be more than 9,800 people and $\$ 859$ million (2010 U.S. dollars). Hurricanes Irma and Maria in 2017 caused widespread damage to coral reefs in the State of Florida and the Commonwealth of Puerto Rico. These damages were measured in post-storm surveys of reefs and assessed in terms of their impact on reef condition and height, which are critical parameters for evaluating the coastal defense benefits of reefs. We combined engineering, ecologic, geospatial, social, and economic data and tools to value the increased risks in Florida and Puerto Rico from hurricane-induced damages to their adjacent coral reefs. We followed risk-based valuation approaches to map flooding at 10-square-meter resolution along all 980 kilometers of Florida and Puerto Rico's reef-lined shorelines considering reef condition before (undamaged) and after (damaged) the 2017 hurricanes. We quantified the coastal flood risk increase caused by the hurricane-induced damage to the coral reefs using the latest information from the U.S. Census Bureau, Federal Emergency Management Agency, and Bureau of Economic Analysis for return-interval storm events. Using the damages associated with each storm probability, we also calculated the change in annual expected damages, a measure of the annual protection lost because of the reef damage caused by the 2017 hurricanes. We found that the damages to the coral reefs off Florida and Puerto Rico from Hurricanes Irma and Maria increased future risks significantly. In particular, we estimated the protection lost by Florida and Puerto Rico's coral reefs from the 2017 hurricanes to result in:

- Increased flooding to more than 10.72 square kilometers (4.14 square miles) of land annually;

${ }^{1}$ U.S. Geological Survey.

${ }^{2}$ University of California at Santa Cruz.

${ }^{3}$ National Oceanic and Atmospheric Administration.
- Increased flooding affecting more than 4,300 people annually;

- Increased direct damages of more than $\$ 57.2$ million to more than 1,800 buildings annually; and

- Increased indirect damages to more \$124.3 million in economic activity owing to housing and business damage annually.

Thus, the annual value of increased flood risk caused by the damage to Florida and Puerto Rico's coral reefs from hurricanes in 2017 is more than 4,300 people and \$181.5 million (2010 U.S. dollars) in economic impacts. These data provide stakeholders and decision makers with a spatially explicit, rigorous valuation of how, where, and when the damage from the 2017 hurricanes decreased critical coastal storm flood reduction benefits to Florida and Puerto Rico's coral reefs. These results help identify areas where reef management, recovery, and restoration could potentially help reduce the risk to, and increase the resiliency of, Florida and Puerto Rico's coastal communities.

\section{Introduction}

Coastal flooding and erosion from extreme weather events affect thousands of vulnerable coastal communities. The impacts of coastal flooding are predicted to worsen during this century because of population growth and climate change (Hallegatte and others, 2013; Hinkel and others, 2014; Reguero and others, 2015, 2018; Storlazzi and others, 2018). There is an urgent need to develop better risk reduction and adaptation strategies to reduce coastal flooding and associated hazards (Hinkel and others, 2014; National Research Council, 2014). For example, the United States spends, on average, $\$ 500$ million per year mitigating such coastal hazards (Federal Emergency Management Agency, 2016a).

Coral reefs, in particular, can substantially reduce coastal flooding and erosion by dissipating up to 97 percent of incident wave energy (Ferrario and others, 2014). Reefs function like low-crested structures such as breakwaters and exhibit hydrodynamic behavior well characterized by coastal engineering models (Hoeke and others, 2011; Taebi and Pattiaratchi, 2014; Reguero and others, 2018). Recently, a process-based, high-resolution, non-linear model of coastal 
protection benefits provided by corals reefs, mapped these natural defense benefits at a resolution relevant to management scales for all populated U.S. coral reef-lined coasts (Storlazzi and others, 2019). The model also provides a framework to rigorously value the people and property protected by coral reefs under numerous current and future climates.

Hurricane Irma skirted the Commonwealth of Puerto Rico on September 7, 2017, and then struck the State of Florida as a Category 4 hurricane on September 10, 2017 (Cangialosi and others, 2018). Hurricane Irma caused dozens of deaths and more than $\$ 50$ billion in damage, thus being the costliest storm in the history of the State of Florida. Ten days later, Hurricane Maria, the strongest weather system to impact Puerto Rico since Hurricane San Felipe II in 1928, made landfall on the south coast of Puerto Rico as a Category 4 hurricane on September 20, 2017 (Pasch and others, 2018). Hurricane Maria caused thousands of deaths, more than $\$ 90$ billion in damage, and the biggest electrical blackout in U.S. history (Federal Communications Commission, 2018). The 2017 hurricane season was the most expensive on record and caused more than $\$ 200$ billion in losses, over of which approximately $\$ 90$ billion was insured losses (Frost and Bove, 2017).
As part of the Federal government's recovery and restoration efforts, the National Oceanic and Atmospheric Administration (NOAA) conducted underwater surveys after the hurricanes to assess the damage to Florida and Puerto Rico's coral reefs (Viehman and others, 2018, 2020a, 2020b). To better understand the role that storm-induced damage to coral reefs play in increasing the risk to, and decreasing the resilience of, reef-lined coastal communities, the U.S. Geological Survey (USGS) worked with the University of California at Santa Cruz (UCSC) and NOAA to assess and quantify, in social and economic terms, the impact of reef damage from Hurricanes Irma and Maria in Florida and Puerto Rico on flood risk to their coastal communities.

\section{Methodology}

Engineering, ecologic, social, and economic data and tools were combined to provide a quantitative valuation of the reduction in coastal protection benefits caused by the 2017 hurricanes' damage to the coral reefs off the State of Florida and the Commonwealth of Puerto Rico (fig. 1). The goal of this effort was to identify how, where, and when hurricane-induced

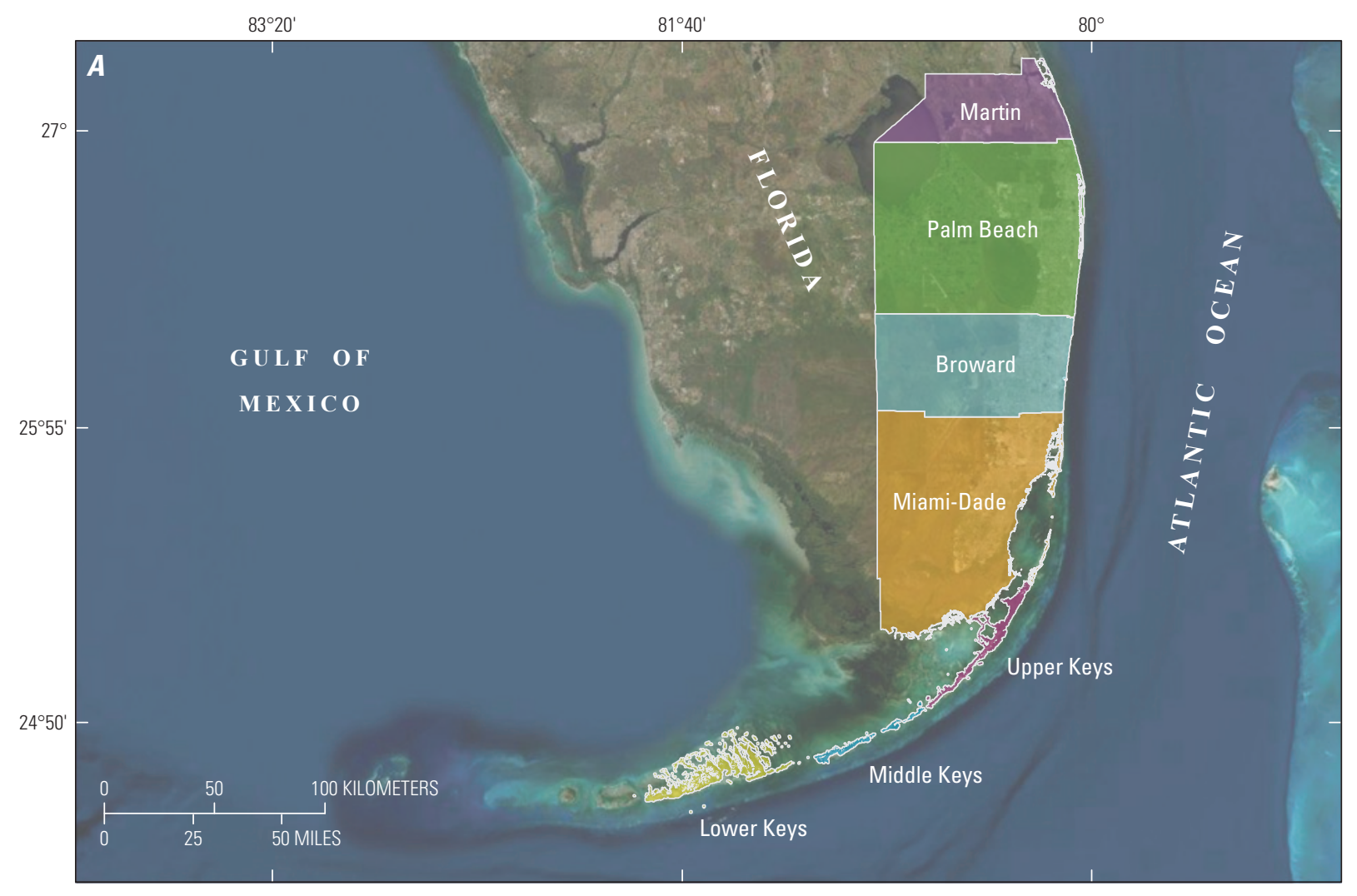

Figure 1. Map indicating the location of the study areas in Florida $(A)$ and Puerto Rico $(B)$. 


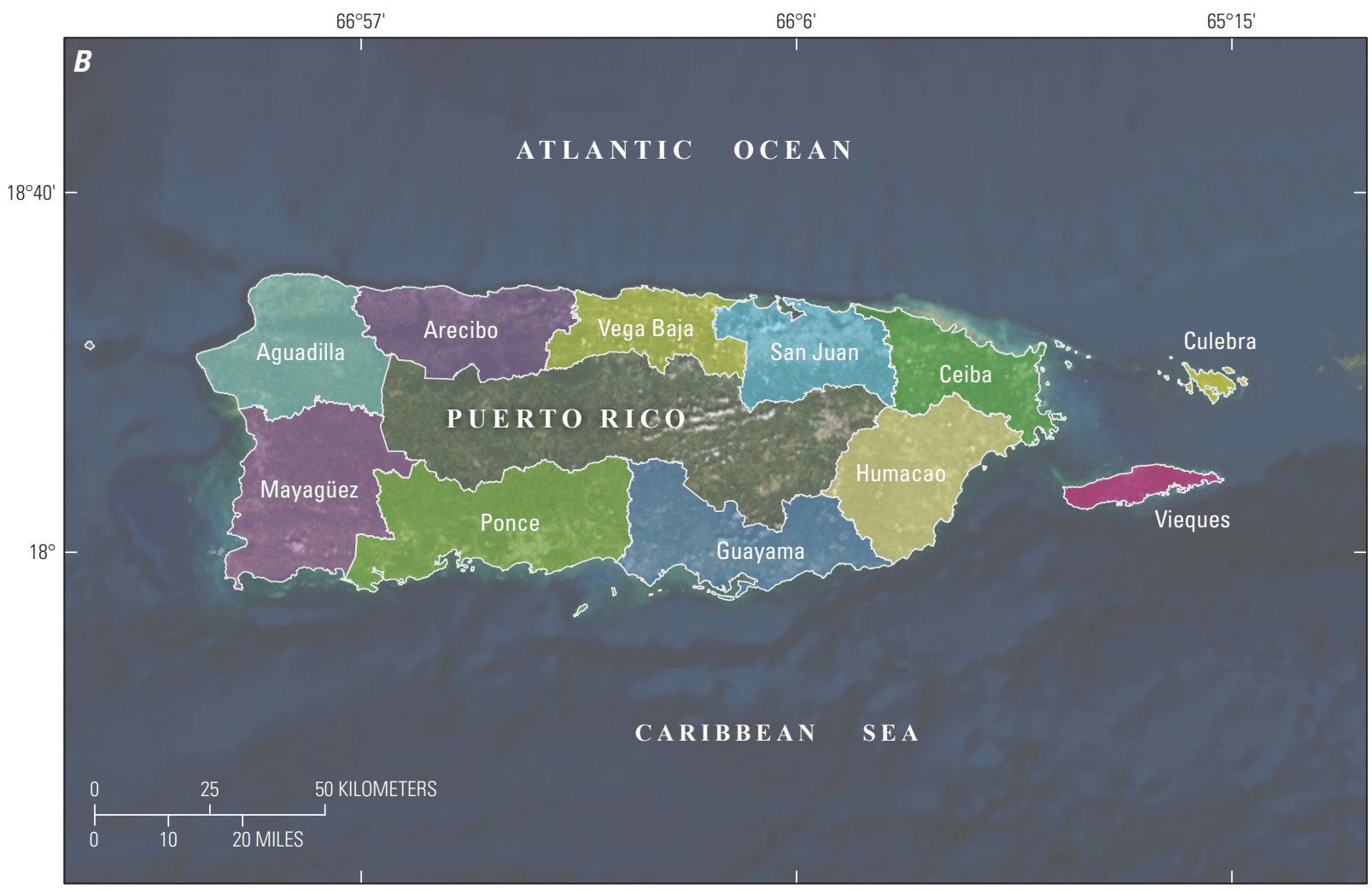

Figure 1. Continued

damage to coral reefs decreased coastal flood reduction benefits socially and economically. This analysis follows a risk quantification valuation framework to estimate the risk reduction benefits from coral reefs and provide annual expected benefits in social and economic terms (Storlazzi and others, 2019). This study represents the first unique and innovative effort to rigorously quantify the increase in coastal hazard risk caused by hurricane-induced storm damage to coral reefs, based on high-resolution flooding modeling and state-of-the-art damage modeling and calculations based on approaches used by the Federal Emergency Management Agency (FEMA) and the U.S. Army Corps of Engineers (USACE). The methods follow a sequence of steps (fig. 2) derived from Storlazzi and others (2019) that integrate physics-based hydrodynamic modeling, quantitative geospatial modeling, and social and economic analyses to quantify the hazard, the role of hurricaneinduced damage to coral reefs in increasing coastal flooding, and the economic and social consequences.

\section{Projecting the Coastal Hazards}

Sixty-one years (1948-2008) of validated long-term, hourly hindcast deep-water wave data were extracted from the Global Ocean Wave (GOW) database (Reguero and others, 2012) for the populated, reef-lined coastal areas of Florida and Puerto Rico (fig. 2A). Following the methodology of Camus and others (2011), we propagated more than half a million hourly data on wave climate parameters to the nearshore shore using a hybrid downscaling approach. The offshore wave climate data were synthesized into 500 combinations of sea states (wave height, wave periods, and wave directions) that best represented the range of conditions from the GOW database (fig. $2 B$ ). These selected sea states were then propagated to the coast using the physics-based Simulating Waves Nearshore (SWAN) spectral wave model (Booij and others, 1999; Ris and others, 1999; Delft University of Technology, 2016), which simulates wave transformations 


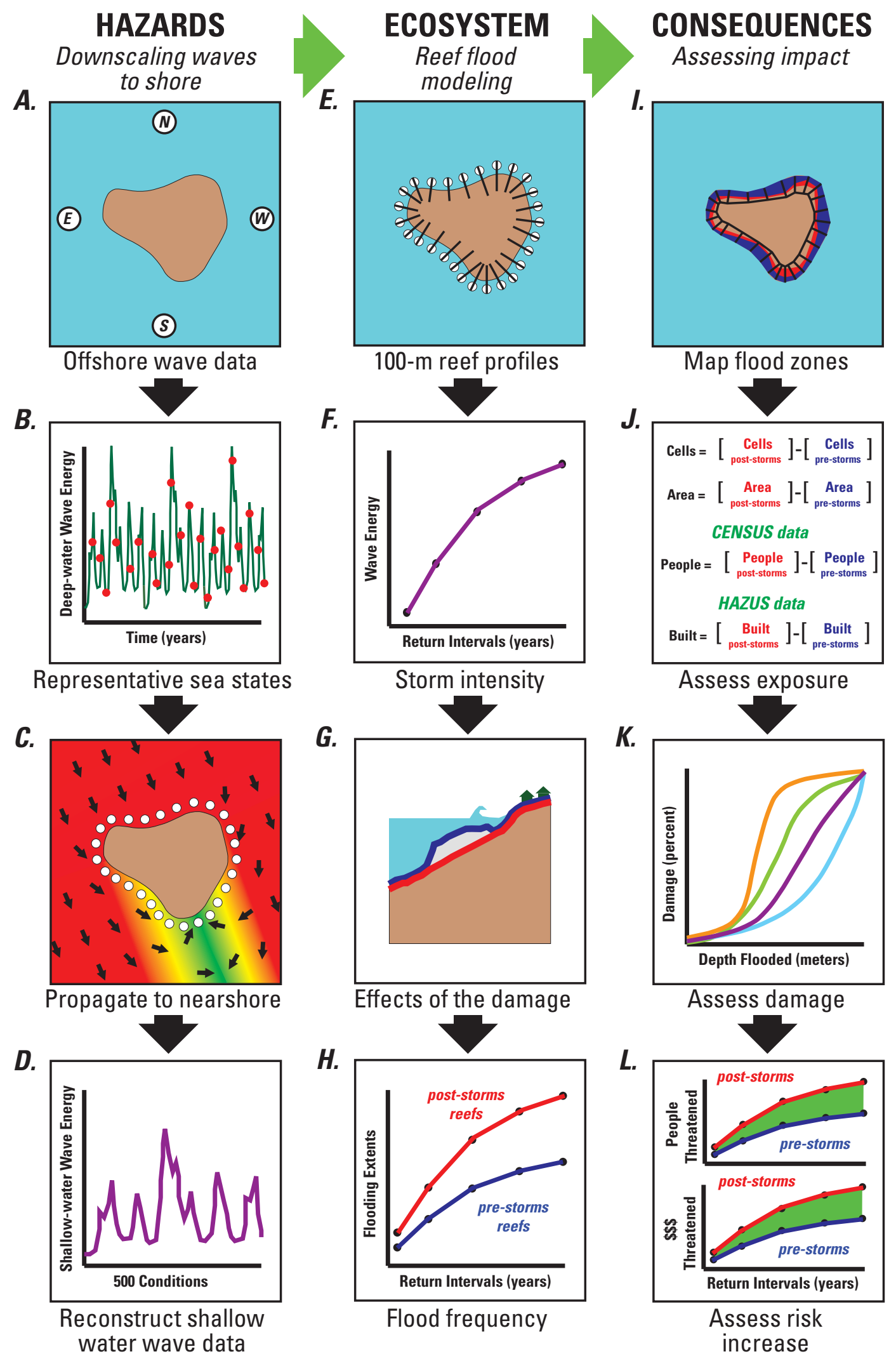

Figure 2. Schematic diagram that shows the methodology used to evaluate the increase in coastal flooding hazard risk owing to hurricane-induced damage to coral reefs. Modified after Storlazzi and others (2019). Each step is described in more detail in the methodology section. $\mathrm{m}$, meter. 
nearshore by solving the spectral action balance equation (fig. 2C). Wave propagation around reef-lined islands has been accurately simulated using SWAN (Hoeke and others, 2011; Taebi and Pattiaratchi, 2014; Storlazzi and others, 2015). Standard SWAN settings were used (for example, Hoeke and others, 2011; Storlazzi and others, 2015), except that the directional spectrum was refined to 5 -degree bins (72 total) to better simulate refraction and diffraction in and amongst islands (appendix 1).

To accurately model from the scale of the island groups or large sections of coastline (order of 10s of kilometers $[\mathrm{km}]$ ) to management scales (order of 100 s of meters [m]), a series of two dynamically downscaled nested, rectilinear grids were used. The coarse (1-km resolution) SWAN grids provided spatially varying boundary conditions for finerscale (200-m resolution) SWAN grids (fig. 3). The bathymetry for the SWAN grids were generated by grid-cell averaging of various topobathymetric digital elevation (DEM) models (appendix 2). The propagated 500 shallow-water wave conditions from the finest SWAN grids were extracted at 100 - $\mathrm{m}$ intervals along the coastline, at a water depth of $30 \mathrm{~m}$ (fig. 2D), and then reconstructed into hourly time series using multidimensional interpolation techniques (Camus and others, 2011).
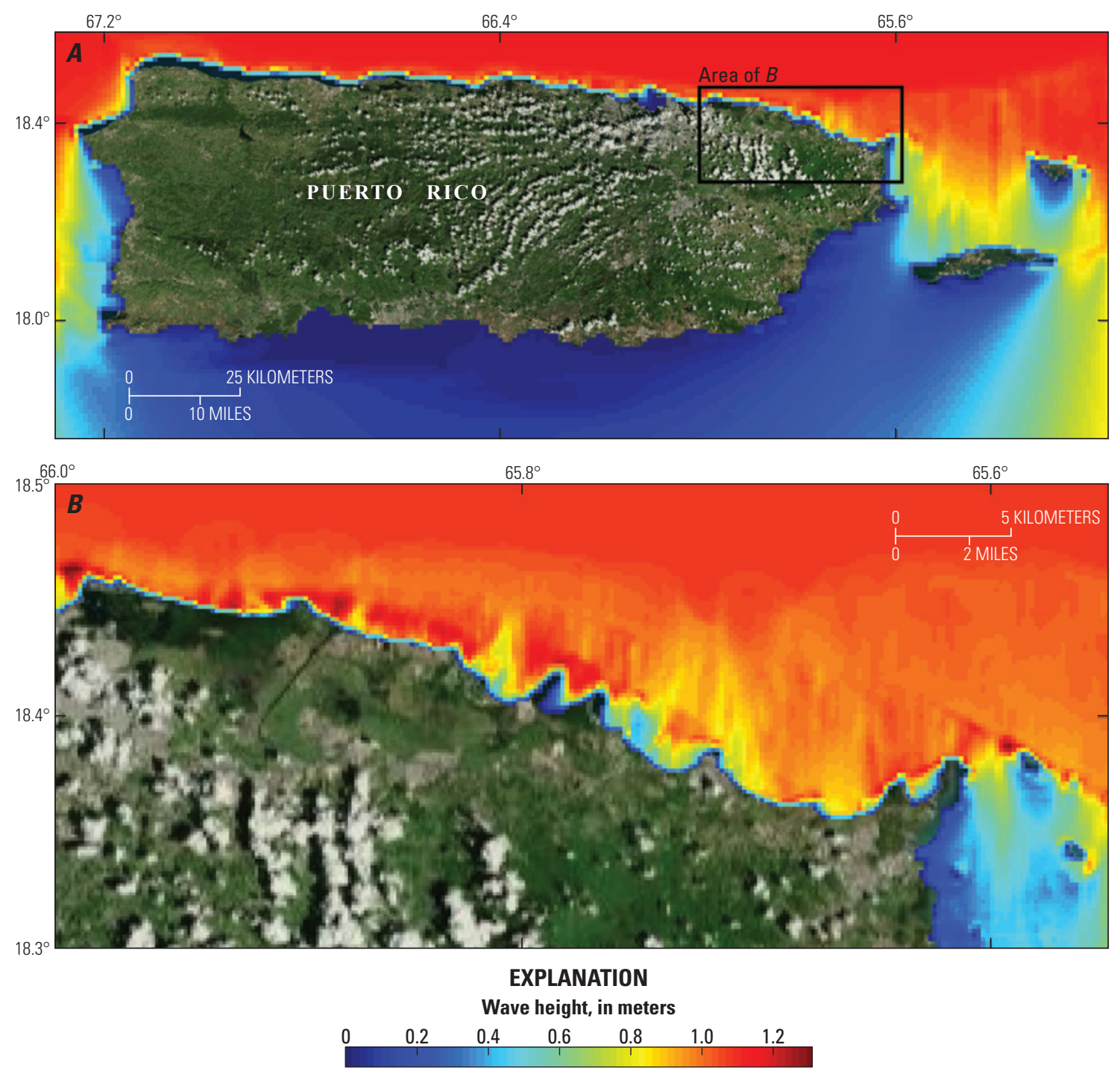

Figure 3. Maps showing output examples of the Simulating Waves Nearshore (SWAN) model and how one of the 500 wave conditions was dynamically downscaled to the 200-meter grid scale offshore northeastern Puerto Rico. $A$, The 1-kilometer $(\mathrm{km})$ resolution Puerto Rico model. $B$, The 200-m resolution northeastern Puerto Rico model embedded in the $1-\mathrm{km}$ Puerto Rico model. Colors indicate significant wave height, in meters. The black rectangle in subplot $A$ indicates the extent of the area in subplot $B$. 


\section{Evaluating the Role of Coral Reefs in Coastal Protection}

Benthic habitat maps defining coral reef spatial extent and coral cover percentage (appendix 3) were used to delineate the location of nearshore coral reefs and their relative coral abundance along the reef-lined shorelines (fig. 4). Cross-shore transects were created every $100 \mathrm{~m}$ alongshore (appendix 4) using the Digital Shoreline Analysis System (DSAS) software version 4.3 in ArcGIS version 10.3 (Thieler and others, 2009). Transects were cast in both landward and seaward directions using the smoothed baseline cast method with a 500-m smoothing distance, perpendicular to a baseline generated from coastlines digitized from USGS 1:24,000 quadrangle maps and smoothed in ArcGIS using the polynomial approximation with exponential kernal algorithm and a 5,000 m smoothing tolerance (fig. 2E). Transects varied in absolute length to ensure each intersected the $-30 \mathrm{~m}$ and $+20 \mathrm{~m}$ elevation contours. The bathymetric (appendix 5) and coral cover (appendix 3) data were extracted along these shore-normal transects at a grid-cell cross-shore resolution of $1 \mathrm{~m}$.

The nearshore wave time series (hourly data from 1948 to 2008) were fit to a General Extreme Value (GEV) distribution (Méndez and others, 2006; Menéndez and Woodworth, 2010) to obtain the significant wave heights associated with the 10-, 50-, 100-, and 500-year storm return periods (fig. 2F). The corresponding 10-, 50-, 100-, and 500 -year storm return period extreme water levels for a given location were taken from the nearest National Oceanic and Atmospheric Administration (NOAA) tidal station (National Oceanic and Atmospheric Administration, 2017), which include the effects of tropical cyclones.

The return-value significant wave heights and associated peak periods were then propagated over the coral reefs with corresponding return-value sea levels along 100-m spaced shore-normal transects (appendix 4) using the numerical model XBeach (Roelvink and others, 2009; Deltares, 2016), as demonstrated in figures $2 G$ and 4 . XBeach solves for

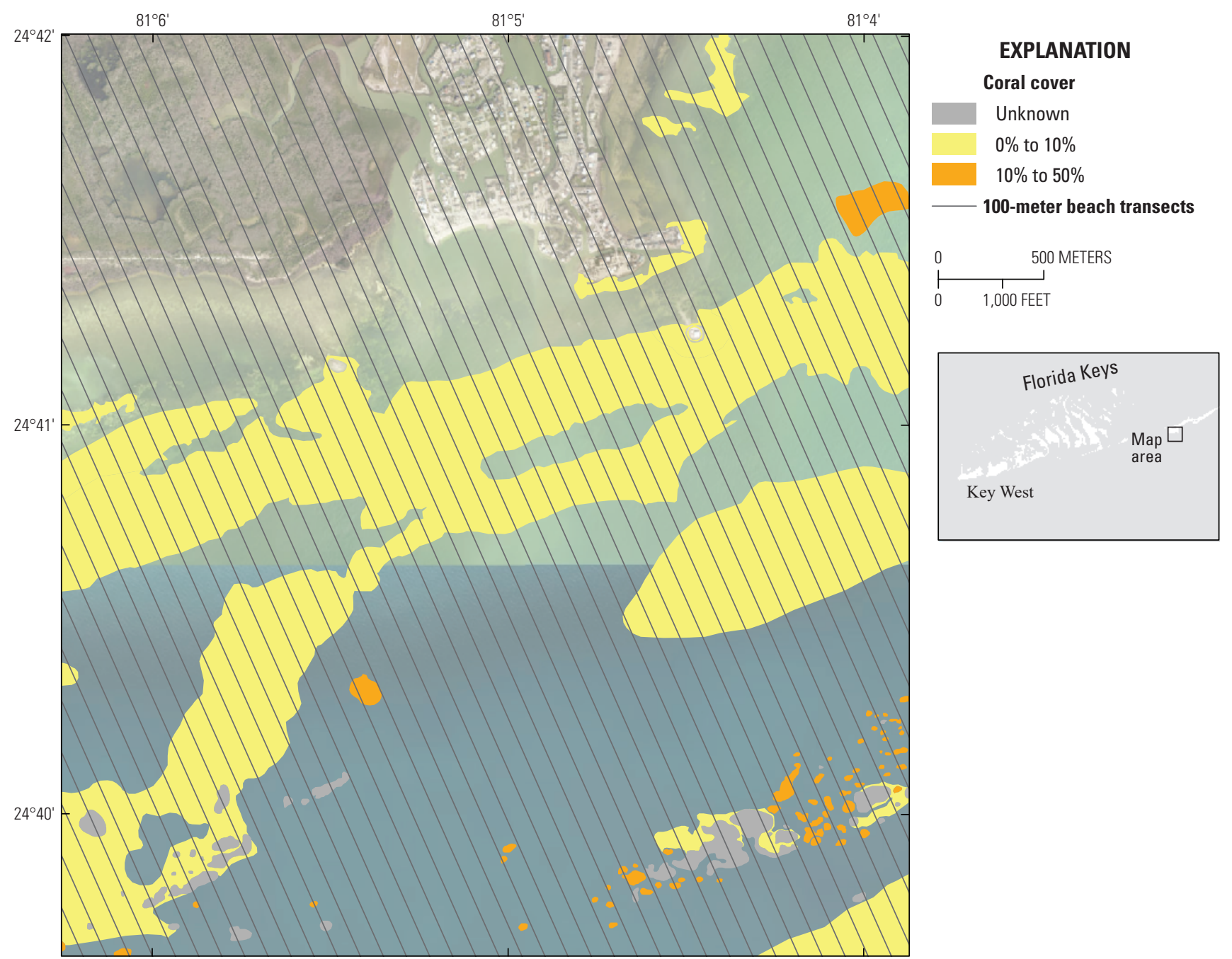

Figure 4. Example map showing the coral extent and coverage (Florida Fish and Wildlife Conservation Commission, 2016) and XBeach transects offshore Marathon, Vaca Key, Florida. Colors indicate percentage (\%) of coral coverage; black lines show cross-beach transects at 100 -meter (m) intervals. 
water-level variations up to the scale of long (infragravity) waves using the depth-averaged, non-linear shallow-water equations. The forcing is provided by a coupled wave action balance in which the spatial and temporal variations of wave energy due to the incident-period wave groups are solved. The radiation stress gradients derived from these variations result in a wave force that is included in the nonlinear shallow-water equations and generates long waves and water level setup within the model. Although XBeach was originally derived for mild-sloping sandy beaches, with some additional formulations, it has been applied in reef environments (Pomeroy and others, 2012; van Dongeren and others, 20132009; Quataert and others, 2015; Storlazzi and others, 2018) and proved to accurately predict the key reef hydrodynamics.

XBeach was run for 3,600 seconds (s) in one-dimensional hydrostatic mode along the cross-shore transects, at a varying resolution between $10 \mathrm{~m}$ seawards and $1 \mathrm{~m}$ landwards (resolution varies depending on depth); the runs generally stabilized after 100-150 s and thus generated good statistics on waves and wave-driven water levels for more than 50 minutes (appendix 6). The application of a one-dimensional model neglects some of the dynamics that occur on natural reefs, such as lateral flow. However, it does represent a conservative estimate for infragravity wave generation and wave runup, as the forcing is shore normal. As stated above, the choice is warranted in this case because the observations show nearnormally offshore waves (such as wave propagation modeled with SWAN).

The additional formulations that incorporate the effect of higher bottom roughness on incident wave decay through the incident wave friction coefficient $\left(f_{w}\right)$ and the current and infragravity wave friction coefficient $\left(c_{f}\right)$, as outlined by van Dongeren and others (2013), were applied. The friction induced by corals was parameterized based on the spatially varying coral coverage data and results from a meta-analysis of wave breaking studies over various reef configurations and friction coefficients for the different coral coverages (for example, van Dongeren and others, 2013; Quataert and others, 2015). Coral coverage classes, as established by the benthic habitat maps, were assigned $f_{w}$ and $c_{f}$ (table 1 ) over the spatial extent of the reef along the profile as defined from the benthic habitat maps (appendix 3). Profiles of total water levels (setup plus runup)

Table 1. Wave and current friction coefficients for different percentages of coral cover as determined from benthic habitat maps following Storlazzi and others (2019).

\begin{tabular}{lcc}
\hline $\begin{array}{c}\text { Coral coverage, } \\
\text { in percent }\end{array}$ & $\begin{array}{c}\text { Wave friction } \\
\text { coefficient }\left(\boldsymbol{f}_{\boldsymbol{w}}\right)\end{array}$ & $\begin{array}{c}\text { Current and infragravity } \\
\text { wave friction coefficient }\left(\boldsymbol{c}_{\boldsymbol{f}}\right)\end{array}$ \\
\hline None (sand) & 0.10 & 0.01 \\
$0-10$ & 0.15 & 0.07 \\
$10-50$ & 0.30 & 0.10 \\
$50-90$ & 0.45 & 0.13 \\
$90-100$ & 0.60 & 0.15 \\
\hline
\end{tabular}

at each grid cell over the profiles were then extracted to define the wave-driven flooding along each of the profiles.

\section{Evaluating the Role of Hurricane-induced Storm Damage to Coral Reefs in Reducing Coastal Protection}

Assessments of hurricane-related effects on coral reefs were conducted in October 2017 after Hurricane Irma in the Florida Keys (Viehman and others, 2018) and between MarchMay 2018 after Hurricane Maria in Puerto Rico (Viehman and others, 2020a, 2020b). In both locations, divers used both transect surveys at pre-determined locations and roving surveys at targeted sites to quantify the amount of damage to coral colonies and to reef structure. Site depths ranged from 2.1-29.4 m (7-70 feet [ft]) in Florida and 0.3-8.5 m (1-28 ft) in Puerto Rico. Observed damage to corals and (or) reef structure included fragmentation, breakage, dislodgement from the substrate, and overturned colonies or reef structure. Abrasion was also observed but not included in these analyses.

Transect and roving survey interim classification values defined by Viehman and others (2018, 2020a, and 2020b) were compared, and the greater damage value was selected for use. In Florida, 63 sites were used and assessed based on coral survey transect data utilizing coral size and damage (for example, breakage, overturned, dislodged, not damaged). Qualitative roving surveys were mined for key word information (for example, small, large, extra-large) to label roving data sites with an interim category consistent with transect categories of damage. In Puerto Rico, a combination of roving and transect assessment surveys across 150 sites were used, where damage was determined by observed damage (for example, fragments, overturning, breakage, dislodging) and then binned by coral size and number of damaged corals. The roving data were compressed to the site level, combined with the impact transect data, and binned into impact categories. Site-level damage prevalence was calculated by dividing the total number of damaged colonies by the total number of corals per site. Damage prevalence was then distributed into classifications of impact level, where $0=$ no impact, $0-0.05=$ minor impact, $0.05-0.15=$ moderate impact, and 0.15-1.00= major impact. Categories were converted into numeric values of $0,1,2$, and 3 that corresponded with the none, minor, moderate, and major damage category, respectively. These damage category values were interpolated using inverse distance weighting and clipped to coral and hardbottom extent. The clipped categories were converted into raster datasets for model input (fig. 5).

Transect depth profiles were modified to reflect poststorm conditions by intersecting each profile with first a coral coverage class raster and then a reef damage raster that categorized the degree of damage from 0 (no damage) to 3 (major damage). There were 5 classes of coral cover raster described within the data set up: sand, $0-10$ percent coral uncolonized hardbottom, 10-50 percent coral colonized hardbottom, 50-90 percent coral colonization, and more than 


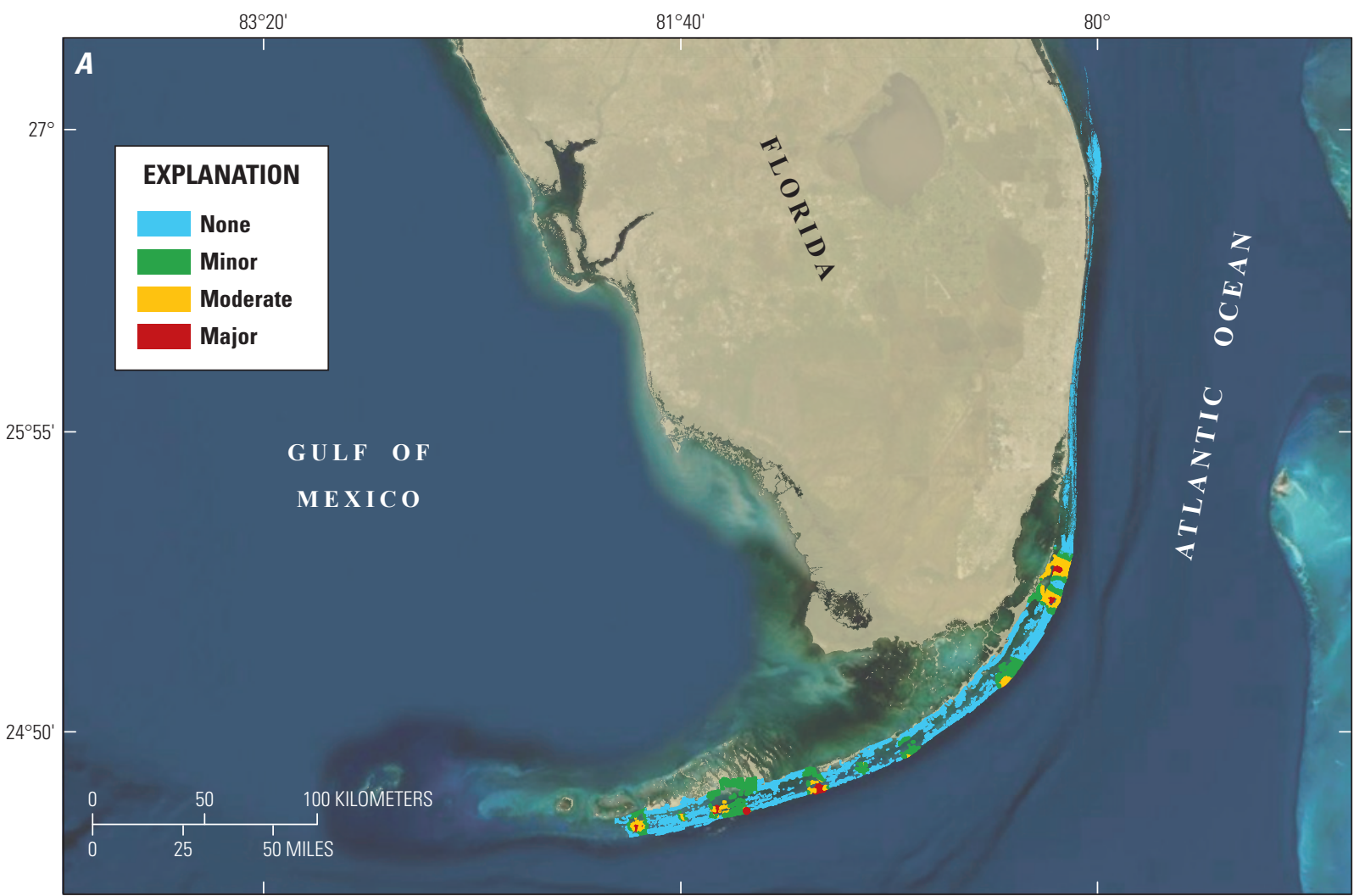

$66^{\circ} 57^{\prime}$

$66^{\circ} 6^{\prime}$

$65^{\circ} 15^{\prime}$

B

A T L A N T I C OCEA N

$18^{\circ} 40^{\prime}$

$18^{\circ}$

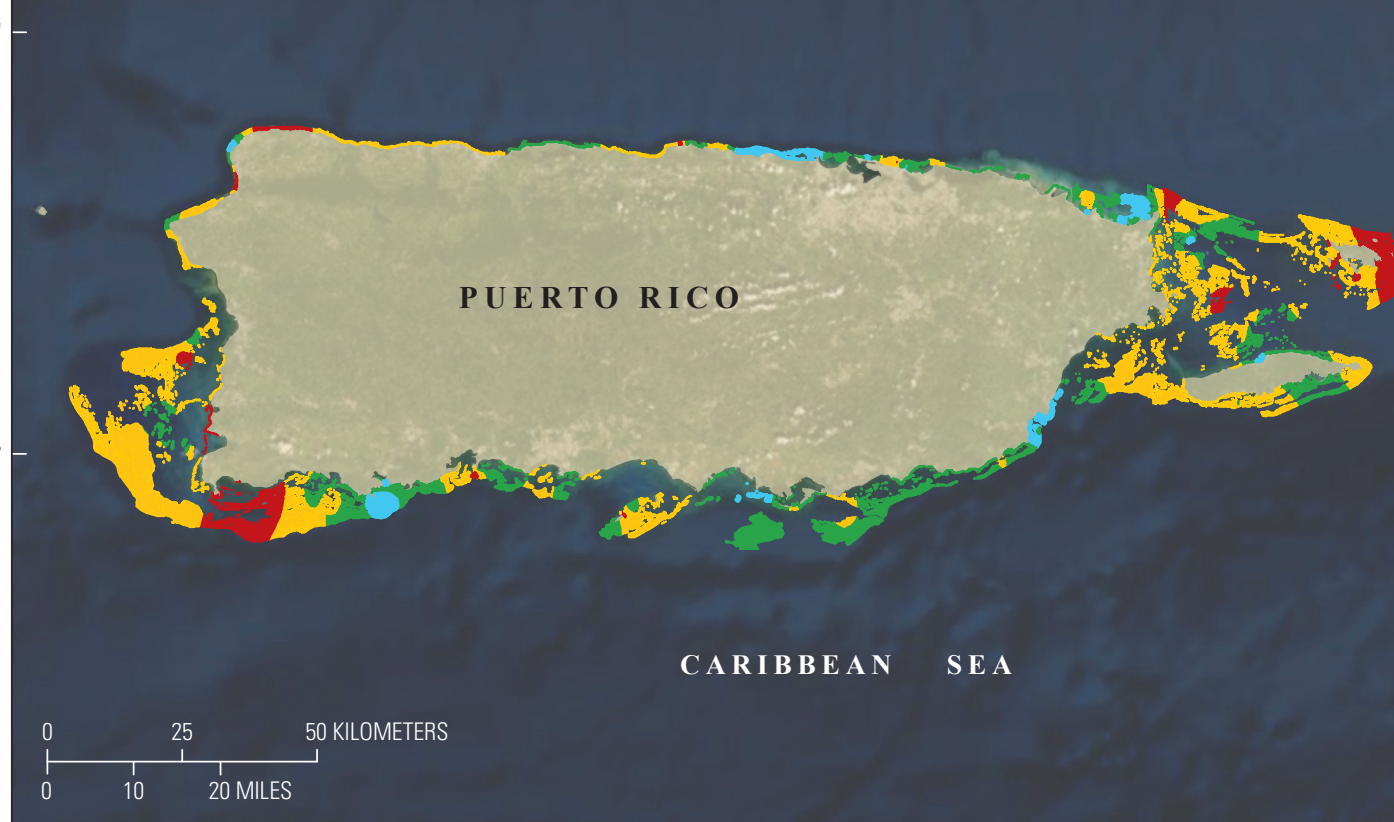

Figure 5. Maps showing example extent and magnitude of damage to the coral reefs caused by the 2017 Hurricanes in (A) Florida and (B) Puerto Rico, based on Viehman and others (2018, 2020a, 2020b). Colors indicate magnitude of coral damage (damage category). 
90 percent coral colonization. The greater colonization results in higher rugosity and thus hydrodynamic roughness via friction and was parameterized per van Dongeren and others (2013) and Quataert and others (2015). Where the locations along each transect were coincident with one of the damageassessment locations, a reduction in roughness, $f_{w}$ and $c_{f}$ (table 1), and (or) an increase in profile depth, were applied. The changes to bathymetry and roughness were then carried on to each Xbeach model run to ascertain the change in flooding from large events because of the damage of the reefs.

For a damage category of 0 (none), no changes to the default bathymetry and roughness values were made, with the assumption that negligible damage would not cause significant modifications. A damage category of 1 (minor) resulted in no change in bathymetry, and a decrease in hydrodynamic roughness that corresponded to a downgrade of coral coverage by one class. For example, at a point with a damage degree of 1 on the damage raster, the associated hydrodynamic roughness would be represented by a downgrade from a $10-50$ percent original coverage class to $0-10$ percent coverage.

A damage category of 2 (moderate) resulted in a decrease in hydrodynamic roughness that corresponded to a downgrade in coral coverage by 2 classes with a decrease in associated hydrodynamic roughness and an increase in depth (a decrease in reef height) by $0.10 \mathrm{~m}$. This simulates the increase in depth associated with partially removing the reef structure. Finally, a damage category of 3 (major) resulted in a downgrade of coverage and roughness by 2 classes, thus a 50-90 percent coral coverage class was reduced to a $0-10$ percent class. Also, the depth at locations with a damage degree of 3 was increased by $0.50 \mathrm{~m}$ to simulate extensive damage to the reef system.

Regions with a damage category of 3 were rare compared to the other values. Often a single transect would intersect multiple damage degree values, and reductions in roughness and increases in depth were applied to the appropriate sections of the transect overlapping the different damages. Finally, there was no class of coverage lower than sand ( 0 percent coral cover), and computationally if a damage category indicated that the coverage downgrade would be lower than a sandy bottom, the roughness was set to that of sand.

The wave and sea level conditions were then propagated using the XBeach model over the same 100-m spaced shorenormal transects modified to account for the damage to the coral reefs (fig. $2 G$ ). Profiles of total water levels (setup plus runup) at each grid cell over the profiles were then extracted to define the wave-driven flooding along these profiles with the hurricane-induced damage to the coral reefs (fig. 6).

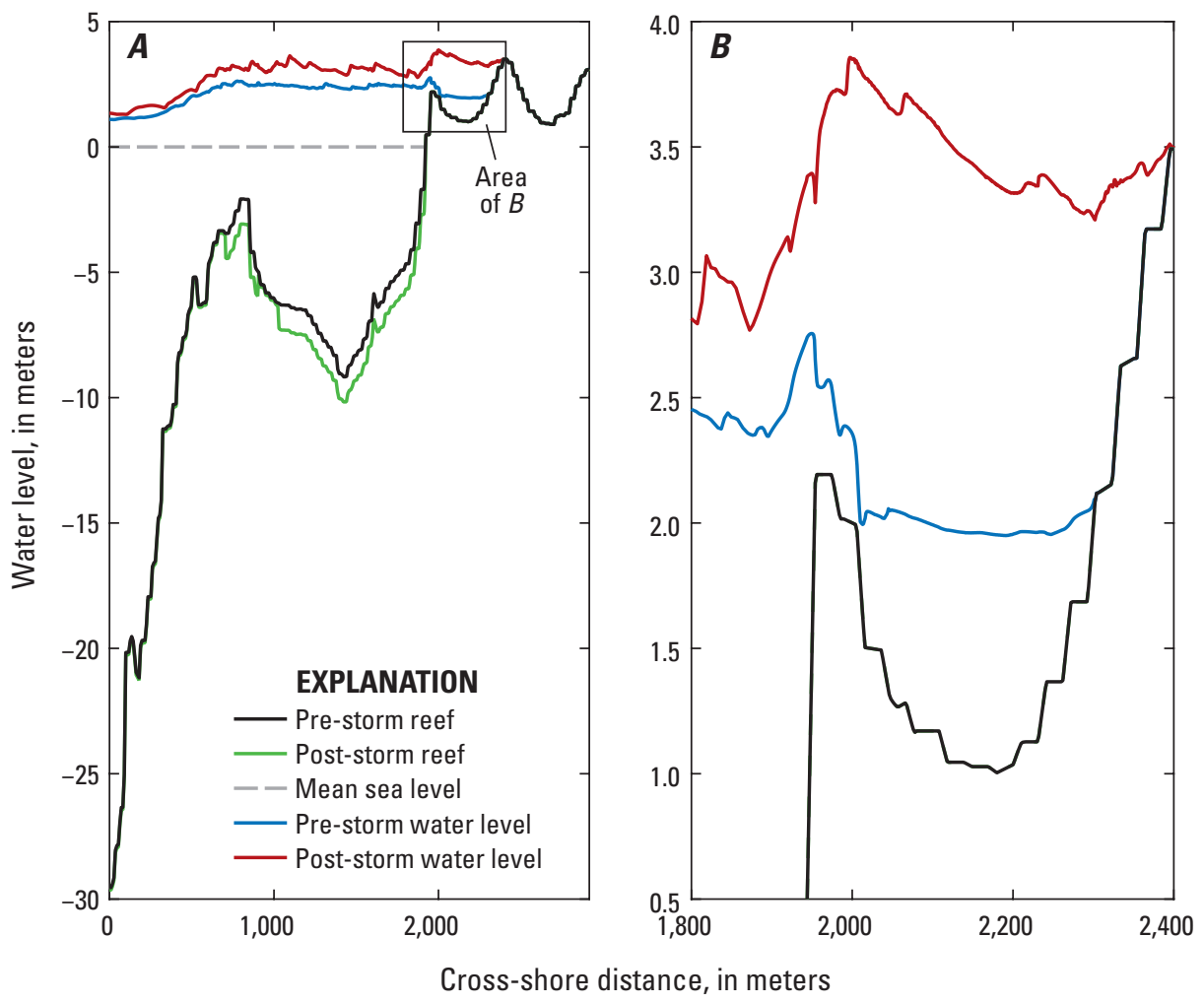

Figure 6. Plots of Puerto Rico example topographic-bathymetric cross-sections and XBeach model wave-driven total water levels during the 100-year storm before the hurricanes and after the hurricane-induced damage to the coral reefs. $A$, Cross-shore profile 1469 offshore San Juan. B, Zoomed-in view of profile 1469. The black line denotes bathymetry and the blue line the total water levels (setup plus runup) with pre-hurricane coral reefs, the green line denotes the region of coral reef damage, and the red line the total water levels resulting from the hurricane-induced damage to the coral reefs. Note the high vertical exaggeration. 


\section{Quantifying the Social and Economic Impact of Coral Reef Damage}

Wave-driven total water level depths and extents were then interpolated between adjacent shore-normal transects for the four return intervals (fig. $2 H$ ) to develop flood mask layers for both pre-storms and post-storms coral reef conditions (fig. 2I). The flood masks were derived by creating an interpolated flood surface raster with values representing absolute water level (flood depth + elevation) and then taking the difference between that surface and the elevation. The extent of the water depth raster defined the flood mask (fig. 7). Any pixels with a positive value were retained as flood-water depth (fig. 8). To correct areas of disconnected backshore pooling, any pixel regions that were discontinuous with the coastline were removed. The resultant raster was then converted to a polygon feature class and clipped by a land polygon feature class derived from the DEM (where values were greater than zero). Finally, to account for stochasticity of XBeach model runs, the flood mask output polygons were put through a series of topological rules for the flooded pixels where, for each return period: pre-storm scenario $<$ poststorm scenario, and for each scenario: 10-year return period $<50$-year return period $<100$-year return period $<500$-year return period.

The flood surface used to derive the flood masks was computed as the product of a natural neighbor interpolation of XBeach model flood points (points in space, and include information on flood water depth and elevation along each transect spaced $100 \mathrm{~m}$ ) and a distance-weighted multiplier between 0 and 1, calculated as an exponential function of distance from the flood extent along each transect. Within $50 \mathrm{~m}$ of the flooded section of each transect, the multiplier is equal to 1 (in application, retaining 100 percent of the interpolated flood value) and exponentially decreases to 0 at a distance of $500 \mathrm{~m}$ (no flooding regardless of interpolated flood value). This method allowed for a more realistic flood zone to be created between transects while honoring the known flood extents.

In Puerto Rico, which contains regions that do not have parallel transect incidence angles (high crenulation) and thus consistent cross-shore transect spacing, points were generated between the intersection point of each transect

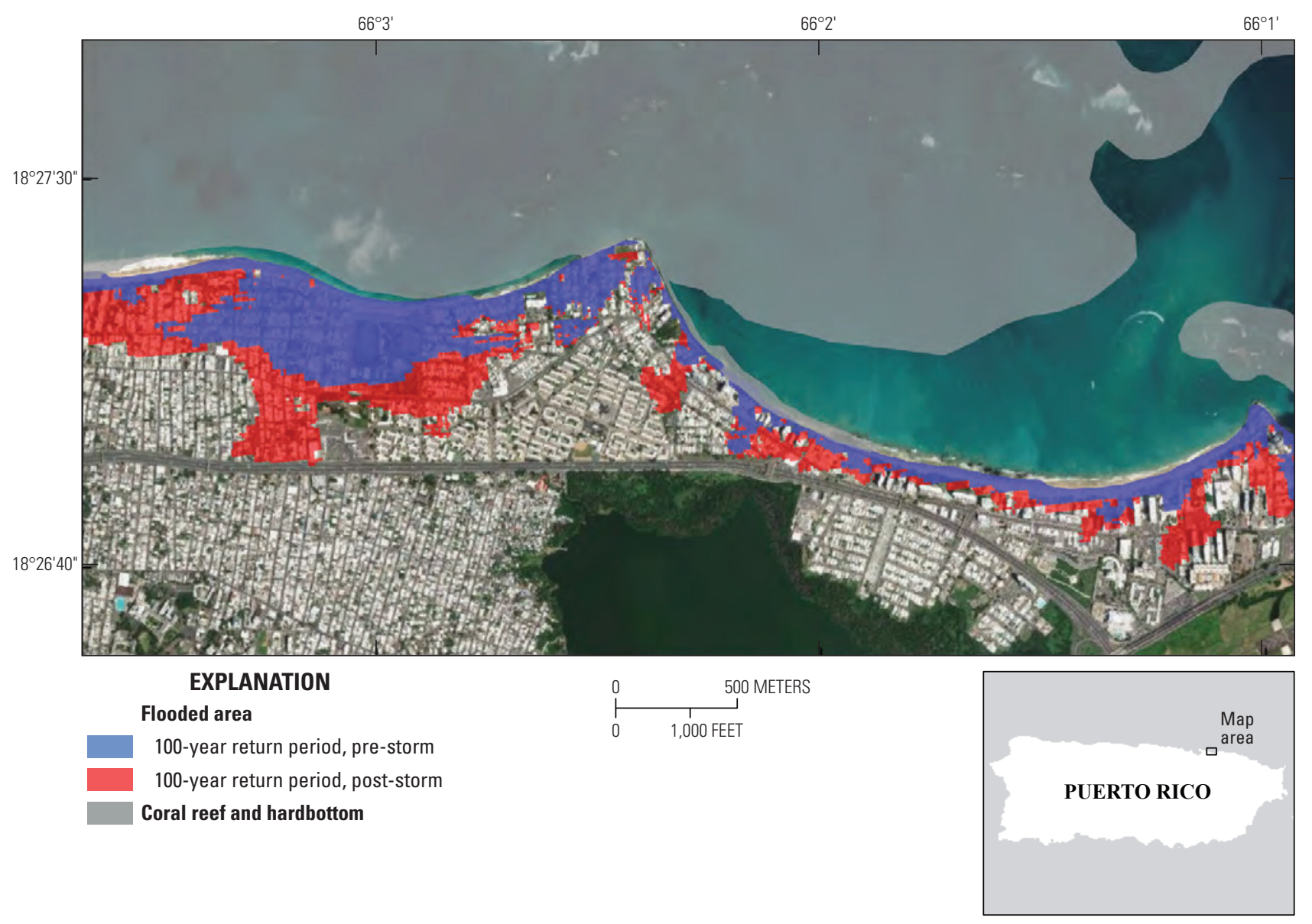

Figure 7. Map showing example 100-year floodplains for pre-storms and post-storms coral reef conditions on eastern San Juan, Puerto Rico. The blue regions denote the floodplains with pre-storms coral reefs, and the red regions denote the floodplains for post-storms coral reefs. Note that the post-storm floodplain overlaps with and includes the pre-storm floodplain. The region now exposed to coastal flooding because of the hurricane-induced storm damage to the coral reefs for the 100-year return-interval storm is the red band. 


\section{A. 10-year return interval}

$81^{\circ} 48$

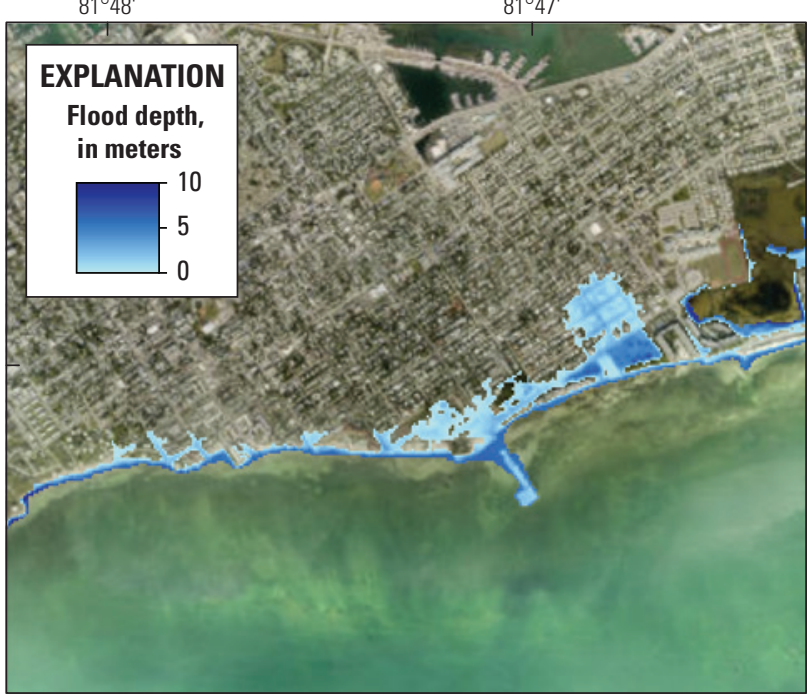

\section{100-year return interval}

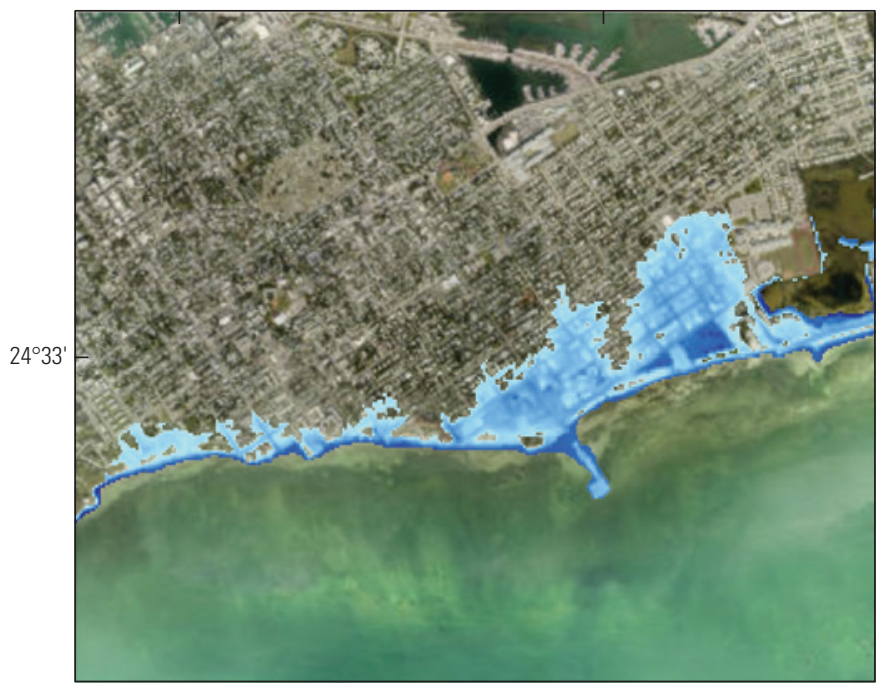

0
B. 50-year return interval

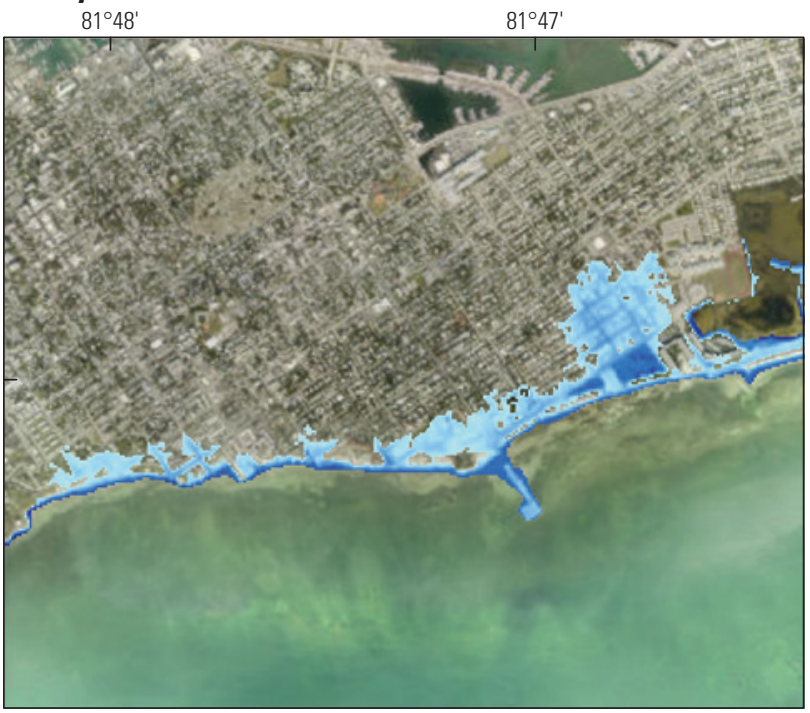

D. 500-year return interval

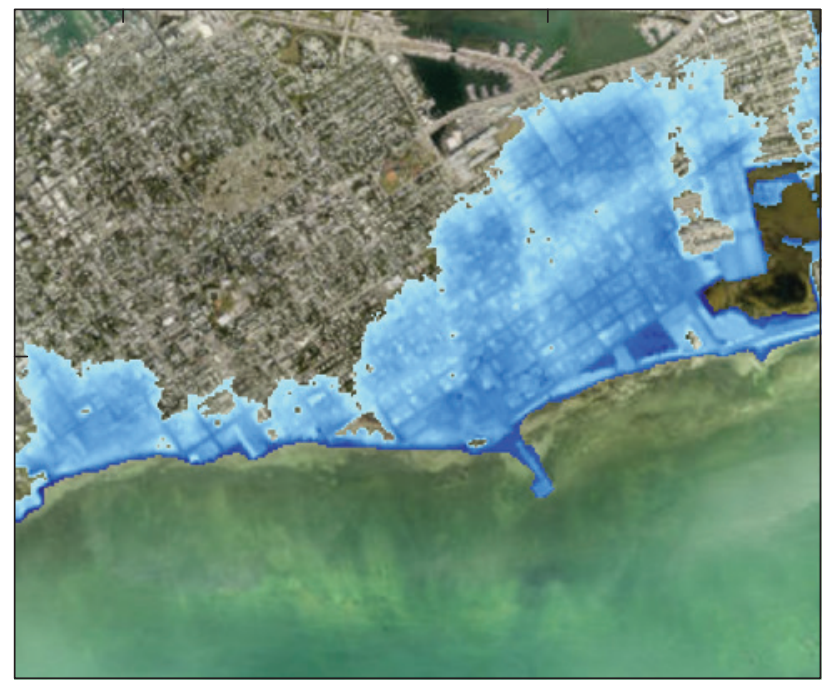

1 MILE

1 KILOMETER

Figure 8. Maps showing example 10-meter $(\mathrm{m})$ resolution flood depths for various storm recurrence intervals on Key West, Florida. A, 10-year storm. B, 50-year storm. C, 100-year storm. D, 500-year storm. Colors indicate flood-water depth, in meters, interpolated from adjacent XBeach model profile model transects spaced every 100-m along the coast.

and the coastline at intervals of about $20 \mathrm{~m}$. The mean water level of all flood points for each transect was calculated and a linear interpolation of these values between each transect pair was applied to each successive point along the coast between transect intersections. These points were merged with the XBeach model flood points prior to the natural neighbor interpolation in Puerto Rico to augment gaps between the modeled XBeach flood points. For each flood mask, the cells flooded by wave-driven setup and runup for both scenarios were logged and areas computed (fig. $2 J$ ).
The resulting number of people threatened, building damage, and indirect economic impact were then computed using the wave-driven flood depths. The people impacted by wave-driven flooding were determined by cross-referencing the flooded cells with the U.S. Census Bureau's (2016) TIGER database, as shown in figure 9. The number of people at risk from flooding were calculated from the intersection between the flood depth raster and people per unit area. The built infrastructure impacted by wave-driven flooding was determined by cross-referencing the flooded cells with the 


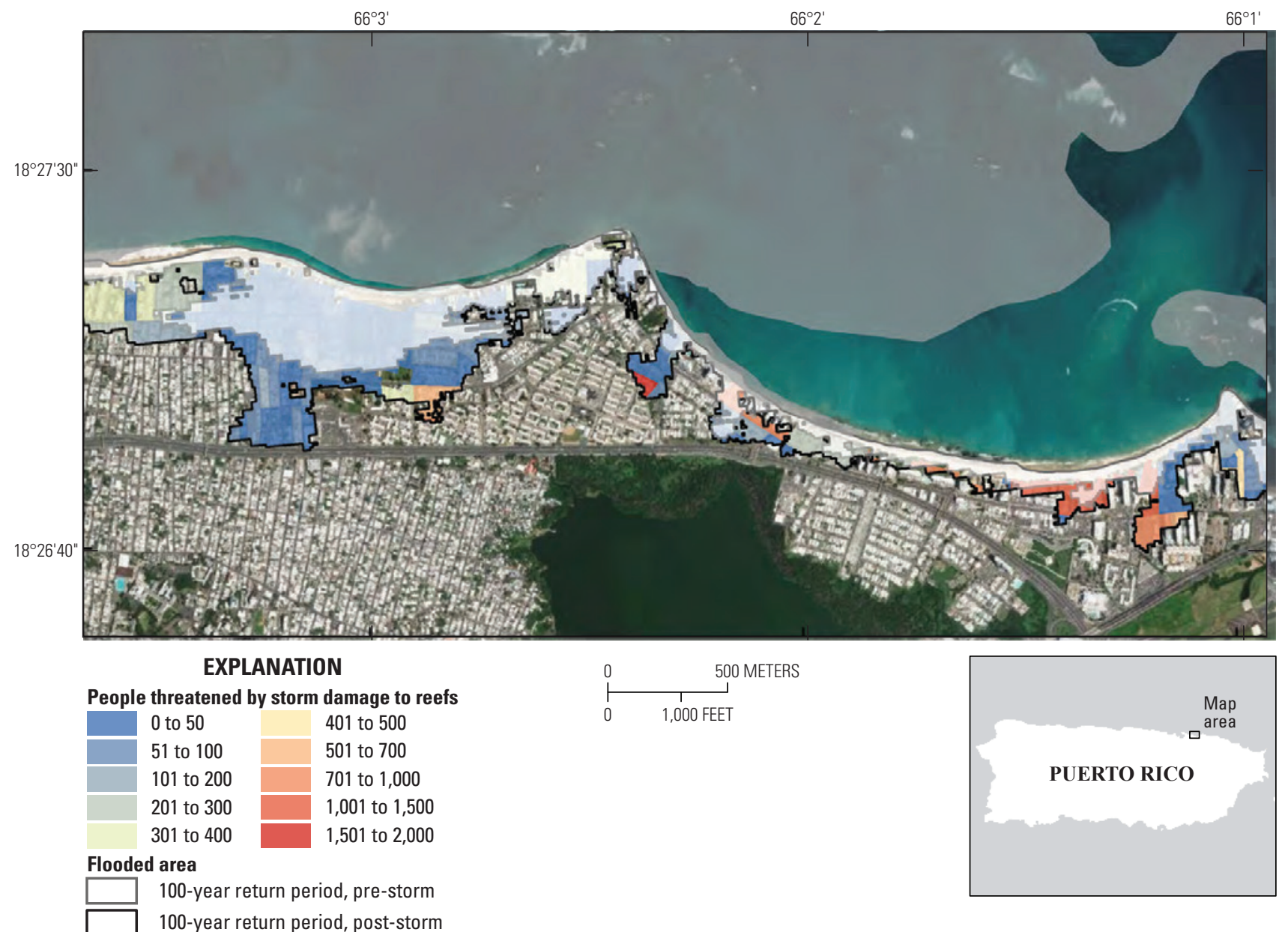

Coral reef and hardbottom

Figure 9. Map showing the distribution of people now exposed to coastal flooding because of the hurricane-induced storm damage to the coral reefs for the 100-year storm eastern San Juan, Puerto Rico. Colors indicate population density, based on U.S. Census Bureau's TIGER data, in the area now exposed to flooding.

Federal Emergency Management Agency's (2016b) flood hazard exposure data in the HAZUS database (Scawthorn and others, 2006a, 2006b). The data were projected into each respective Universal Transverse Mercator Coordinate System (coordinate system from the transects belonging to that region).

For each type of HAZUS asset (for example, different types of residential, commercial and industrial buildings), a damage degree raster was created using the damage functions found in HAZUS (fig. $2 K$ ) for the different categories of infrastructure following the methodology of Wood and others (2013), as shown in figure 10. These damage functions relate flood-water depth with the degree of damage (percentage of damage to each type of building). The damage degree raster was built from the flood depth raster and every cell represents the degree (or percent) of damage from flooding, with values ranging from 0.0 (no damage) to 1.0 (complete damage). Once the damage degree rasters were built, the economic value of the damage (in 2010 U.S. dollars) was calculated for each asset: building value per unit area multiplied by degree of damage. Similarly, the number and extent of flooded buildings were calculated by intersections between the flood depth raster and buildings (and specific building types) per unit area, as shown in figure 10. Finally, building damage, number of flooded buildings, and people flooded were aggregated to summary points. The summary points were created as regularly $10-\mathrm{m}$ spaced points within the union between all flood extents. Each point was assigned a transect ID and coral cover attribute based on nearest transect.

The value of the damage to coral reefs in terms of increased coastal hazard risk was then determined as the difference in people and infrastructure impacted by wavedriven flooding in the simulations for the pre-storms coral reef conditions compared to those conditions after the storms (fig. 2L) based on the Viehman and others (2018, 2020a, $2020 \mathrm{~b})$ surveys. The calculated damages by infrastructure type were aggregated and summarized into tables (see results section) for each return period. The infrastructure was categorized into the types of the general building stock 
that includes residential, commercial, industrial, agricultural, religious, government, and education buildings. Damage was estimated in percent and weighted by the area of flooding at a given depth for a given HAZUS census block. The entire composition of the general building stock within a given census block was assumed to be evenly distributed throughout the block.

A storm return period, $t_{i}$, also known as a recurrence interval, is the inverse of the probability of occurring and an estimate of the likelihood of such a storm event. For example, a 100-year return period of a flood represents a probability of the flood occurring in a given year of 1/100. The damages associated with the probability of occurrence characterize risk for the two reef scenarios: pre-storms and post-storms coral reef conditions. The expected annual damage (EAD) is the frequency-weighted sum of damages for the full range of possible damaging flood events and is a measure of what might be expected to occur in a given year. The EAD was calculated from each damage curve (pre-storms and poststorms, figure 10) as:

$$
E A D=\frac{1}{2} \sum_{i=1}^{n}\left(\frac{1}{t_{i}}-\frac{1}{t_{i+1}}\right)\left(D_{i}+D_{i+1}\right)
$$

where:

$E A D \quad$ is the frequency-weighted sum of damages for the full range of possible damaging flood events;

$i \quad$ is the specific storm return period number;

$n \quad$ is the total number of different storm return periods (in this case, $n=4$ );

$t_{i} \quad$ is the storm return period, also known as the recurrence interval; and

$D_{i} \quad$ represents the loss in the damage curve (fig. $2 L$ ) for the probability of $1 / t_{i}$, per Olsen and others (2015).

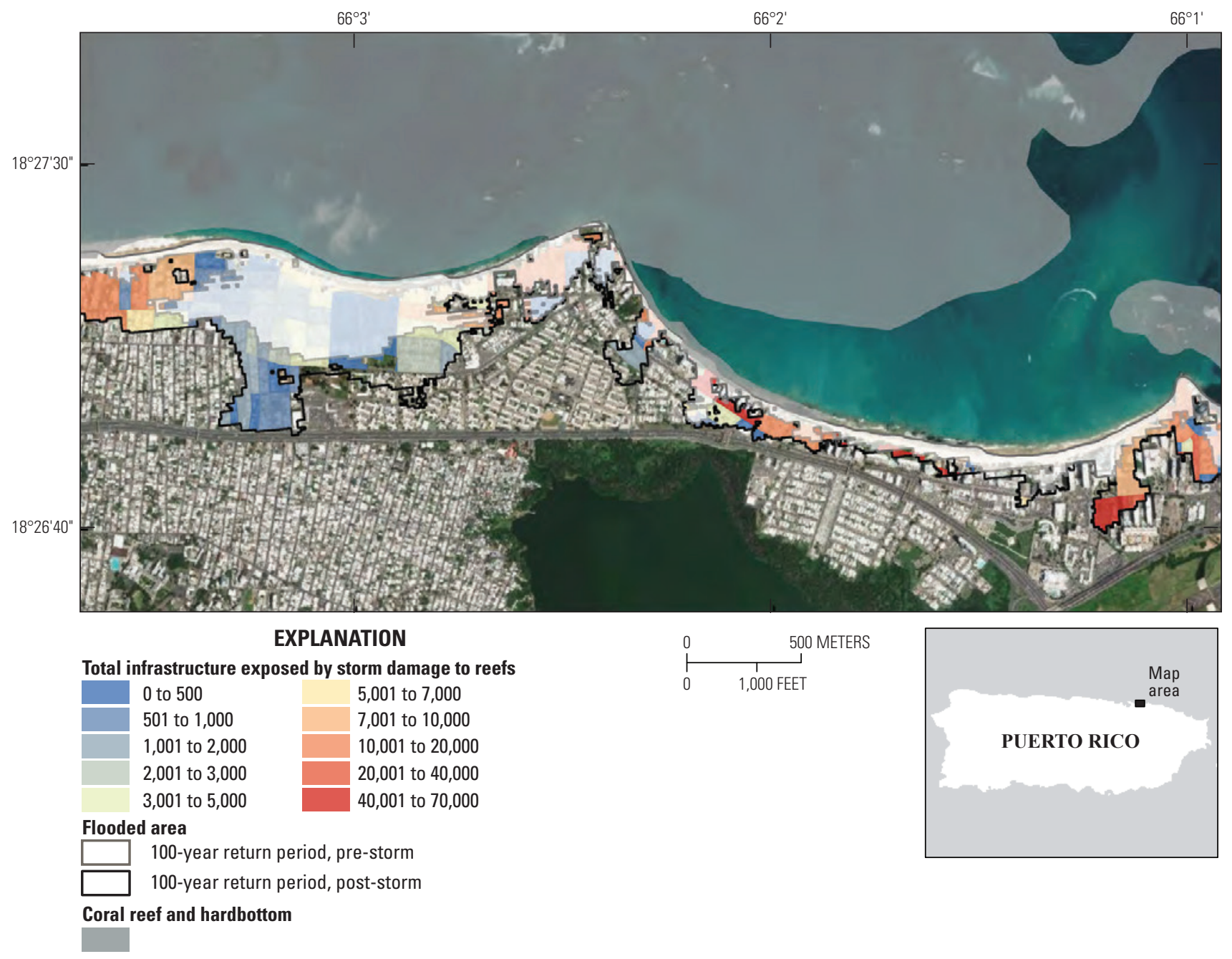

Figure 10. Map showing value of infrastructure, in thousands of 2010 U.S. dollars, now exposed to coastal flooding because of hurricane-induced storm damage to the coral reefs for the 100-year storm eastern San Juan, Puerto Rico. Colors indic ate total value of infrastructure, based on the Federal Emergency Management Agency's HAZUS data, in the area now exposed to flooding. 

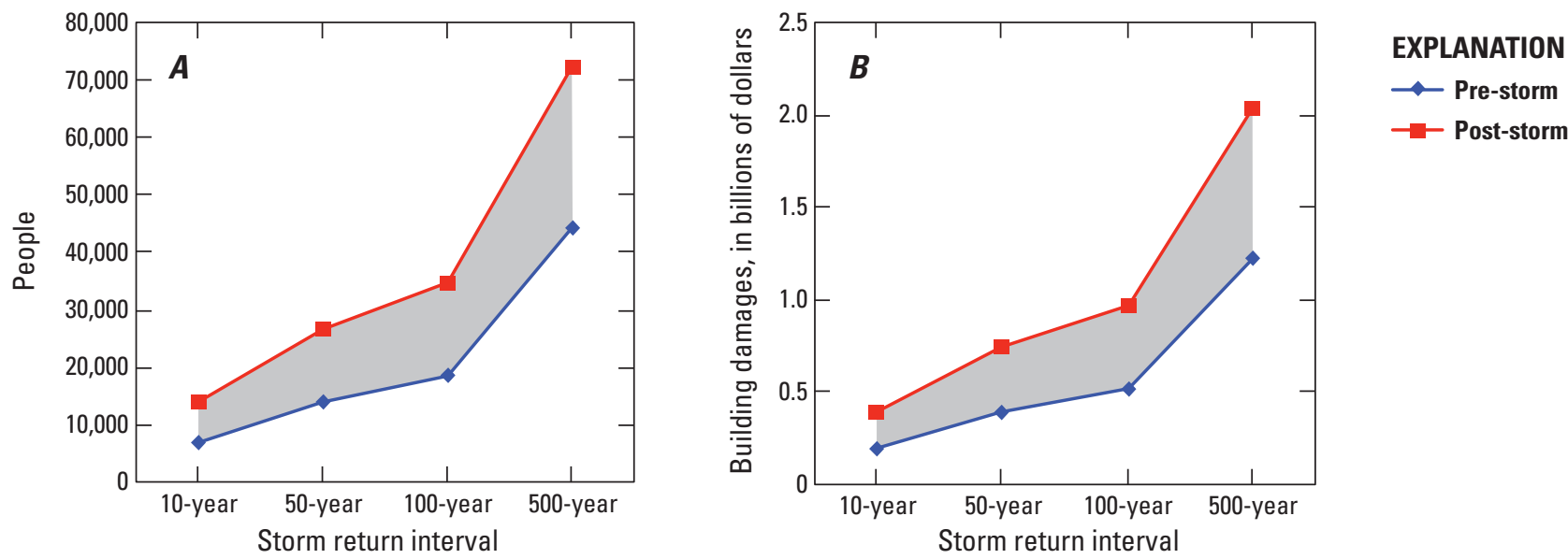

Figure 11. Example plots showing damage curves both for pre-storms and post-storms reef conditions for Puerto Rico. $A$, Number of people displaced by loss of housing from coastal flooding. $B$, Values of damage to buildings by coastal flooding. The gray region denotes the increased exposure to coastal flooding because of the hurricane-induced storm damage to coral reefs.

The benefits were calculated as the difference in damages between the two scenarios: pre-storms and post-storms (fig. 11). The expected annual loss (EAL), a measure of the annual loss of protection provided coral reefs (or increased exposure) because of the projected degradation, is calculated as:

$$
E A L=E A D_{\text {post-storms }}-E A D_{\text {pre-storms }}
$$

The total economic impact of wave-driven coastal flooding, however, is not only the direct physical damage to structures themselves, but also to the disruption of peoples' and businesses' incomes and thus the contribution to the gross domestic product (GDP) of that housing and commercial/ industrial infrastructure, respectively (Federal Emergency Management Agency, 2018). This indirect damage is calculated by multiplying the 2010 average contribution to the GDP per person (table 2; U.S. Bureau of Economic Analysis, 2018) to the number of people living in the regions now exposed to flooding because of the hurricane-induced storm damage to the coral reefs. One can compute the economic activity protected by reefs for people that would be displaced owing to the loss of housing from increased coastal flooding. Similarly, by multiplying the 2010 average of 15.1 employees per business (U.S. Census Bureau, 2018) to the 2010 average contribution to the GDP per person (table 2; U.S. Bureau of Economic Analysis, 2018) to the number of commercial and industrial buildings in the regions now exposed to flooding because of the hurricane-induced storm damage to the coral reefs, one can compute the economic activity lost for businesses impacted by the loss of infrastructure from increased coastal flooding. Because there are no data linking the people living in an area to where those people work, we assume here that the economic activity lost for people displaced by the loss of housing from coastal flooding is independent from the economic activity lost for businesses impacted by the loss of infrastructure from coastal flooding.
Table 2. Gross domestic product (GDP) per person by island or region.

[Data from Bureau of Economic Analysis (2018)]

\begin{tabular}{lc}
\hline \multicolumn{1}{c}{ Location } & GDP (in 2010 U.S. dollars) \\
\hline Florida & 38,604 \\
Puerto Rico & 26,436 \\
\hline
\end{tabular}

\section{Uncertainties, Limitations, and Assumptions}

Numerical flood modeling errors were estimated to be $\pm 0.5 \mathrm{~m}$. This value is greater than the root-mean-square and absolute errors computed between model results and measurements (van Dongeren and others, 2013; Quataert and others, 2015) but was used in an effort to mitigate the fact that the number of storms tested are few and the geographic scope is large compared to regions where validation measurements are available. The vertical resolution of the HAZUS depthdamage curves is $\pm 0.3 \mathrm{~m}$. Uncertainties associated with the baseline DEM varied based on input data; see references listed in appendix 5. Other limitations and assumptions pertaining to flood extents and the resulting computed social and economic consequences include:

- The extreme value analysis for selecting storm return periods was stationary and did not include nonstationary effects (such as interannual patterns like El Niño) in the selection of values. The fit of each time series had to be limited to a number of thresholds and could not be adapted iteratively. These thresholds were also different for each region, depending on the local characteristics of extremes in each time series (including a limit of at least 30 extreme values to fit the extreme value distribution). 
- Because the coral coverage data are defined in 5 classes, the associated hydrodynamic roughness data are also classified in 5 classes. This results in a stepwise change in hydrodynamic roughness that can occur over a relatively small distance defining two different coral coverage class polygons that could result from a small change ( 2 percent; for example, between 9 percent to 11 percent cover) in coral cover.

- The reef damage at specific survey locations was defined by step-wise classes and extrapolated across the reefs. It is unclear as to the accuracy of such projections to the resulting damage across the reefs, possibly overpredicting damage at greater depths where wave energy would have been lower and possibly underpredicting damage in shallower depths where wave energy would have been higher. If that was the case, the overall flooding results would be assumed to be underpredicted, because the shallowwater bathymetry is a primary control on wave energy dissipation, per Scott and others (2020).

- The model scheme used to define the extreme flood levels were a combination of the wave and surge conditions for certain storm probabilities and did not consider dependencies between both variables or the joint distribution of wave heights, wave periods, and surge levels. However, it is likely that large surges and waves occur simultaneously for large return periods.

- We did not consider tide levels beyond those registered in the extreme values measured in the tidal gauges that were used to define the extreme sea level for each region.

- The modeling structure of one-dimensional cross-shore transects assumes shore-normal wave and flooding processes.

- The approach for assessing flood damages and the resulting benefits associated with each probability assumes that the probability of the extreme flooding conditions on the fore reef defines the probability of the flood zones and the resulting flood damages (thus, the 1-in-100-year total water level represents the 1-in100-year damage).

- The most statistically accurate assessment of flood damages would require defining the statistical distribution of damages, instead of flood levels - for example, calculating the extreme economic damages. However, this requires the reconstruction of the runup time series and the calculation of spatial losses associated with each event, which is outside the scope of this work.

- Alternative ways to calculate these statistics of economic damages would imply taking larger simplifications and uncertainties in the modeling of flooding, which would likely affect the accuracy of the results.

- Flood depths and extents between cross-shore transects modeled are alongshore interpolations and are not exact representations of model output, because they did not consider topographic features between the transects.

- U.S. Census Bureau's (2016) TIGER/Line data and FEMA's (2016b) flood hazard exposure data in the HAZUS database are based on the 2010 census, and, thus, may not reflect current-day populations, demographics, building values, and distributions.

- The composition of the general building stock within a given census block was assumed to be evenly distributed throughout the block.

- The 2010 average of 15.1 employees per business was uniformly applied to the number of commercial and industrial buildings to compute the economic activity protected for businesses not impacted by the loss of infrastructure from coastal flooding.

- The economic activity protected for people not displaced by the loss of housing from coastal flooding is independent from the economic activity protected for businesses not impacted by the loss of infrastructure from coastal flooding.

\section{Results}

\section{Flooding Extents}

This section summarizes the loss of coastal flood protection (increased exposure) because of the hurricaneinduced damage to coral reefs for each region considered in the analysis for the 4 storm return periods. The losses are expressed in terms of land surface and number and value of buildings or assets now exposed to coastal flooding owing to the hurricaneinduced damage to the coral reefs. The benefits are calculated as the differences between pre-storms and post-storms coral reef conditions. The EAL, or annual loss of area protected from coastal flooding because of the hurricane-induced damage is 0.45 square kilometers $\left(\mathrm{km}^{2}\right)\left(0.17\right.$ square miles $\left.\left[\mathrm{mi}^{2}\right]\right)$ in Florida and $10.27 \mathrm{~km}^{2}\left(3.97 \mathrm{mi}^{2}\right)$ in Puerto Rico (table 3). 
Table 3. Spatial extent, in square kilometers, of area no longer protected from coastal flooding because of the hurricane-induced damage to coral reefs for different return-interval storms by region.

\begin{tabular}{llcccc}
\hline \multirow{2}{*}{ Location } & \multicolumn{1}{c}{ Sublocation } & \multicolumn{4}{c}{ Storm Return Interval } \\
\cline { 3 - 5 } & Martin & $\mathbf{1 0}$-year & $\mathbf{5 0}$-year & $\mathbf{1 0 0}$-year & $\mathbf{5 0 0}$-year \\
\hline Florida & Palm Beach & 0.00 & 0.00 & 0.00 & 0.00 \\
Florida & Broward & 0.00 & 0.00 & 0.00 & 0.00 \\
Florida & Miami-Dade & 0.01 & 0.00 & 0.00 & 0.00 \\
Florida & Upper Keys & 0.34 & 0.23 & 0.13 & 0.02 \\
Florida & Middle Keys & 0.13 & 0.10 & 0.04 & 0.14 \\
Florida & Lower Keys & 0.00 & 0.00 & 0.00 & 0.00 \\
Florida & San Juan & 0.40 & 0.12 & 0.11 & 3.09 \\
Puerto Rico & Vega Baja & 0.88 & 1.94 & 2.29 & 2.37 \\
Puerto Rico & Arecibo & 1.18 & 2.20 & 2.23 & 3.27 \\
Puerto Rico & Aquadilla & 2.01 & 2.33 & 2.98 & 1.79 \\
Puerto Rico & Mayaguez & 1.97 & 2.33 & 2.17 & 4.74 \\
Puerto Rico & Ponce & 3.61 & 4.17 & 4.06 & 3.30 \\
Puerto Rico & Guayama & 2.35 & 2.84 & 2.66 & 3.76 \\
Puerto Rico & Humacao & 1.50 & 2.10 & 2.16 & 1.27 \\
Puerto Rico & Ceiba & 0.71 & 0.72 & 1.13 & 3.25 \\
Puerto Rico & Culebra & 2.75 & 3.77 & 3.73 & 0.64 \\
Puerto Rico & Vieques & 0.58 & 0.55 & 0.70 & 1.55 \\
Puerto Rico & & 0.50 & 1.16 & 0.99 & \\
\hline
\end{tabular}

\section{Social Impacts}

The expected annual loss, in terms of the annual number of people who lost protection from coastal flooding because of the hurricane-induced damage to coral reefs, is 27 people in Florida and 4,283 people in Puerto Rico (table 4).

\section{Economic Impacts}

The expected annual loss, in terms of the annual number of buildings that lost protection from coastal flooding because of the hurricane-induced damage to coral reefs, is 24 in Florida and 1,820 in Puerto Rico (table 5). The EAL,

Table 4. Total number of people whom lost protection from coastal flooding because of the hurricane-induced damage to coral reefs for different return-interval storms by region.

\begin{tabular}{|c|c|c|c|c|c|}
\hline \multirow{2}{*}{ Location } & \multirow{2}{*}{ Sublocation } & \multicolumn{4}{|c|}{ Storm Return Interval } \\
\hline & & 10-year & 50-year & 100-year & 500-year \\
\hline Florida & Martin & 0 & 0 & 0 & 0 \\
\hline Florida & Broward & 6 & 1 & 0 & 0 \\
\hline Florida & Miami-Dade & 0 & 0 & 0 & 1 \\
\hline Florida & Middle Keys & 0 & 0 & 0 & 0 \\
\hline Florida & Lower Keys & 35 & 55 & 51 & 73 \\
\hline Puerto Rico & San Juan & 2,431 & 5,379 & 6,721 & 15,833 \\
\hline Puerto Rico & Vega Baja & 157 & 404 & 505 & 491 \\
\hline Puerto Rico & Arecibo & 778 & 1,115 & 1,598 & 2,524 \\
\hline
\end{tabular}


Table 4. Continued

\begin{tabular}{llrrrr}
\hline \multirow{2}{*}{ Location } & \multicolumn{1}{c}{ Sublocation } & \multicolumn{4}{c}{ Storm Return Interval } \\
\cline { 3 - 5 } & & 10-year & 50-year & 100-year & 500-year \\
\hline Puerto Rico & Aquadilla & 936 & 1,336 & 1,802 & 953 \\
Puerto Rico & Mayaguez & 1,333 & 1,901 & 2,147 & 4,684 \\
Puerto Rico & Ponce & 379 & 848 & 873 & 691 \\
Puerto Rico & Guayama & 371 & 460 & 587 & 733 \\
Puerto Rico & Humacao & 27 & 58 & 85 & 316 \\
Puerto Rico & Ceiba & 596 & 1,002 & 1,693 & 1,967 \\
Puerto Rico & Culebra & 30 & 32 & 35 & 62 \\
Puerto Rico & Vieques & 25 & 33 & 44 & 55 \\
\hline
\end{tabular}

Table 5. Total number of buildings (all infrastructure types) that lost protection from coastal flooding because of the hurricane-induced damage to coral reefs for different return-interval storms by region.

\begin{tabular}{llcccc}
\hline \multirow{2}{*}{ Location } & \multicolumn{1}{c}{ Sublocation } & \multicolumn{4}{c}{ Storm Return Interval } \\
\cline { 3 - 5 } & & $\mathbf{1 0}$-year & $\mathbf{5 0}$-year & $\mathbf{1 0 0}$-year & 500-year \\
\hline Florida & Martin & 0 & 0 & 0 & 0 \\
Florida & Palm Beach & 0 & 0 & 0 & 0 \\
Florida & Broward & 3 & 0 & 0 & 0 \\
Florida & Miami-Dade & 0 & 0 & 0 & 0 \\
Florida & Upper Keys & 4 & 13 & 9 & 0 \\
Florida & Middle Keys & 0 & 0 & 0 & 44 \\
Florida & Lower Keys & 32 & 53 & 54 & 3,678 \\
Puerto Rico & San Juan & 596 & 1,136 & 1,328 & 327 \\
Puerto Rico & Vega Baja & 141 & 378 & 462 & 1,253 \\
Puerto Rico & Arecibo & 318 & 482 & 734 & 561 \\
Puerto Rico & Aquadilla & 516 & 670 & 825 & 1,657 \\
Puerto Rico & Mayaguez & 743 & 895 & 974 & 315 \\
Puerto Rico & Ponce & 162 & 381 & 385 & 382 \\
Puerto Rico & Guayama & 207 & 282 & 345 & 149 \\
Puerto Rico & Humacao & 15 & 31 & 47 & 85 \\
Puerto Rico & Ceiba & 344 & 502 & 732 & 36 \\
Puerto Rico & Culebra & 24 & 30 & 28 & 36 \\
Puerto Rico & Vieques & 20 & 23 & 27 & \\
\hline
\end{tabular}

in terms of the annual value of buildings that lost protection, is $\$ 1,635,535$ in Florida and $\$ 55,573,197$ in Puerto Rico (table 6). The EAL, in terms of the annual value of economic activity that lost protection is $\$ 1,083,077$ in Florida and
$\$ 113,248,055$ in Puerto Rico (table 7). The total EAL, in terms of the annual value of all lost coastal storm flooding protection (sum of tables 6 and 7) because of the hurricane-induced damage to coral reefs, is $\$ 3,423,010$ in Florida and $\$ 178,142,710$ in Puerto Rico (table 8). 
Table 6. Total value of all infrastructure types that lost protection from coastal flooding because of the hurricane-induced damage to coral reefs for different return-interval storms by region.

[Values in 2010 U.S. dollars]

\begin{tabular}{|c|c|c|c|c|c|}
\hline \multirow{2}{*}{ Location } & \multirow{2}{*}{ Sublocation } & \multicolumn{4}{|c|}{ Storm Return Interval } \\
\hline & & 10-year & 50-year & 100-year & 500-year \\
\hline Florida & Martin & $\$ 0$ & $\$ 0$ & $\$ 0$ & $\$ 0$ \\
\hline Florida & Broward & $\$ 246,331$ & $\$ 2,835$ & $\$ 5,558$ & $\$ 0$ \\
\hline Florida & Miami-Dade & $\$ 14$ & $\$ 24$ & $\$ 135$ & $\$ 21,803$ \\
\hline Florida & Middle Keys & $\$ 485,211$ & $\$ 755,184$ & $\$ 594,333$ & $\$ 746,252$ \\
\hline Florida & Lower Keys & $\$ 1,224,391$ & $\$ 2,333,203$ & $\$ 2,471,819$ & $\$ 3,339,624$ \\
\hline Puerto Rico & San Juan & $\$ 30,537,910$ & $\$ 70,712,273$ & $\$ 85,974,090$ & $\$ 172,710,721$ \\
\hline Puerto Rico & Vega Baja & $\$ 4,800,926$ & $\$ 12,649,364$ & $\$ 16,340,052$ & $\$ 17,493,273$ \\
\hline Puerto Rico & Arecibo & $\$ 7,696,233$ & $\$ 14,394,747$ & $\$ 19,735,782$ & $\$ 35,458,983$ \\
\hline Puerto Rico & Guayama & $\$ 3,998,286$ & $\$ 6,469,237$ & $\$ 7,897,528$ & $\$ 10,754,608$ \\
\hline Puerto Rico & Humacao & $\$ 265,684$ & $\$ 500,049$ & $\$ 814,054$ & $\$ 2,143,190$ \\
\hline Puerto Rico & Ceiba & $\$ 12,339,703$ & $\$ 18,206,199$ & $\$ 25,905,996$ & $\$ 58,033,727$ \\
\hline Puerto Rico & Culebra & $\$ 674,067$ & $\$ 1,001,887$ & $\$ 995,613$ & $\$ 4,273,453$ \\
\hline Puerto Rico & Vieques & $\$ 337,222$ & $\$ 494,649$ & $\$ 512,763$ & $\$ 927,453$ \\
\hline
\end{tabular}

Table 7. Total value of economic activity that lost protection from coastal flooding because of the hurricane-induced damage to coral reefs for different return-interval storms by region.

[Values in 2010 U.S. dollars]

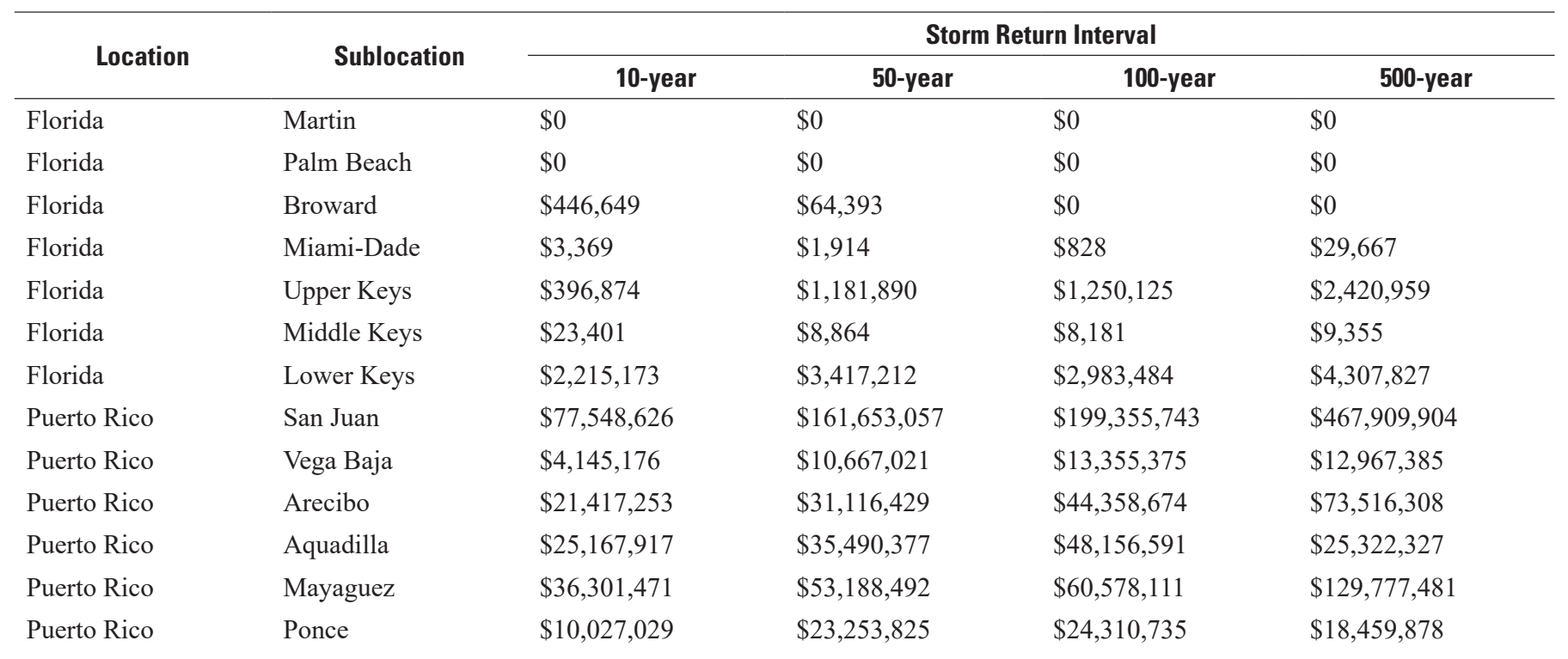


Table 7. Continued

\begin{tabular}{llllll}
\hline \multirow{2}{*}{ Location } & \multicolumn{2}{c}{ Sublocation } & \multicolumn{3}{c}{ Storm Return Interval } \\
\cline { 3 - 6 } & & \multicolumn{1}{c}{$\mathbf{1 0}$-year } & \multicolumn{1}{c}{ 50-year } & \multicolumn{1}{c}{$\mathbf{1 0 0}$-year } & 500-year \\
\hline Puerto Rico & Guayama & $\$ 9,795,486$ & $\$ 12,193,143$ & $\$ 15,987,119$ & $\$ 20,136,207$ \\
Puerto Rico & Humacao & $\$ 721,958$ & $\$ 1,545,545$ & $\$ 2,236,331$ & $\$ 8,346,268$ \\
Puerto Rico & Ceiba & $\$ 15,759,192$ & $\$ 26,589,081$ & $\$ 44,843,060$ & $\$ 52,022,197$ \\
Puerto Rico & Culebra & $\$ 782,445$ & $\$ 841,779$ & $\$ 919,059$ & $\$ 1,647,678$ \\
Puerto Rico & Vieques & $\$ 664,555$ & $\$ 877,788$ & $\$ 1,153,688$ & $\$ 1,453,345$ \\
\hline
\end{tabular}

Table 8. Annual value that lost protection from coastal flooding because of the hurricane-induced damage to coral reefs by region.

\begin{tabular}{|c|c|c|c|c|}
\hline Location & Sublocation & Number of People & Buildings (2010 U.S. dollars) & Economic Activity (2010 U.S. dollars) \\
\hline Florida & Martin & 0 & $\$ 0$ & $\$ 0$ \\
\hline Florida & Palm Beach & 0 & $\$ 0$ & $\$ 0$ \\
\hline Florida & Broward & 3 & $\$ 120,780$ & $\$ 221,756$ \\
\hline Florida & Miami-Dade & 0 & $\$ 92$ & $\$ 1,863$ \\
\hline Florida & Upper Keys & 4 & $\$ 494,043$ & $\$ 268,588$ \\
\hline Florida & Middle Keys & 0 & $\$ 280,070$ & $\$ 11,976$ \\
\hline Florida & Lower Keys & 20 & $\$ 740,550$ & $\$ 1,283,292$ \\
\hline Puerto Rico & San Juan & 1,557 & $\$ 19,610,238$ & $\$ 48,939,056$ \\
\hline Puerto Rico & Vega Baja & 101 & $\$ 3,138,709$ & $\$ 2,683,220$ \\
\hline Puerto Rico & Arecibo & 456 & $\$ 4,738,376$ & $\$ 12,587,987$ \\
\hline Puerto Rico & Aquadilla & 539 & $\$ 8,989,062$ & $\$ 14,464,045$ \\
\hline Puerto Rico & Mayaguez & 777 & $\$ 7,429,642$ & $\$ 21,245,516$ \\
\hline Puerto Rico & Ponce & 235 & $\$ 1,205,935$ & $\$ 6,252,303$ \\
\hline Puerto Rico & Guayama & 210 & $\$ 2,364,372$ & $\$ 5,572,908$ \\
\hline Puerto Rico & Humacao & 18 & $\$ 168,587$ & $\$ 476,821$ \\
\hline Puerto Rico & Ceiba & 360 & $\$ 7,331,022$ & $\$ 9,530,189$ \\
\hline Puerto Rico & Culebra & 16 & $\$ 401,432$ & $\$ 436,140$ \\
\hline Puerto Rico & Vieques & 14 & $\$ 195,823$ & $\$ 381,329$ \\
\hline
\end{tabular}

\section{Conclusions}

Here, we apply a new methodology to combine engineering, ecologic, geospatial, social, and economic tools and data to provide a rigorous social and economic valuation of the coastal protection benefits lost because of damage caused by Hurricanes Irma and Maria in 2017 to coral reefs in the State of Florida and the Commonwealth of Puerto Rico. The resulting data make it possible to identify where, when, and how hurricane-induced damage to coral reefs increases the storm-induced flooding hazards to coastal communities in Florida and Puerto Rico. The goal is to provide sound, scientific guidance for U.S. Federal, State, Commonwealth, and local governments' efforts on hazard risk reduction and coral reef conservation, restoration, and management by providing rigorous, spatially explicit, high-resolution, social and economic valuations of the people and property now exposed to hazards because of hurricane-induced damage to coral reefs to, ultimately, save dollars and protect lives.

\section{Acknowledgments}

This work was carried out by the U.S. Geological Survey (USGS) Coastal and Marine Hazards and Resources Program's Coral Reef Project as part of an effort in the United States and its trust territories to better understand the effect of geologic and oceanographic processes on coral reef systems. This work was supported by U.S. government funding from the 2017 Hurricanes and Wildfire Supplemental. Any use of trade, firm, or product names is for descriptive purposes only and does not imply endorsement by the U.S. Government. 


\section{References Cited}

Booij, N., Ris, R.C., and Holthuijsen, L.H., 1999, A thirdgeneration wave model for coastal regions 1-Model description and validation: Journal of Geophysical Research Oceans, v. 104, p. 7649-7666.

Bureau of Economic Analysis, 2018, Gross Domestic Product database, accessed December 6, 2018, at https://www.bea. gov/data/gdp/gross-domestic-product.

Camus, P., Mendez, F.J., Medina, R., and Cofino, A.S., 2011, Analysis of clustering and selection algorithms for the study of multivariate wave climate: Coastal Engineering, v. 58, no. 6 , p. 453-462.

Cangialosi, J.P., Latto, A.S., and Berg, R.J., 2018, Tropical cyclone report - Hurricane Irma: National Hurricane Center, 111 p., accessed December 17, 2018, at https://www.nhc. noaa.gov/data/tcr/AL112017_Irma.pdf.

Carignan, K.S., McLean, S.J., Eakins, B.W., Beasley, L., Love, M.R., and Sutherland, M., 2015, Digital elevation model of Miami, Florida: National Oceanic and Atmospheric Administration, accessed March 9, 2021, at https:/data. noa..gov//metaview/page?xml=NOAA/NESDIS/NGDC/ MGG/DEM/iso/xml/5270.xml\&view=getDataView\&heade $\mathrm{r}=$ none.

Chapman, M.G., and Underwood, A.J., 2011, Evaluation of ecological engineering of "armoured" shorelines to improve their value as habitat: Journal of Experimental Marine Biology and Ecology, v. 400, p. 302-313, https://doi. org/10.1016/j.jembe.2011.02.025.

Delft University of Technology, 2016, SWAN website, accessed December 19, 2016, at https://www.tudelft.nl/ en/ceg/over-faculteit/departments/hydraulic-engineering/ sections/environmental-fluid-mechanics/research/swan/.

Deltares, 2016, XBeach Open Source Community website, accessed December 19, 2016, at http://oss.deltares.nl/web/ xbeach/.

Federal Communications Commission, 2018, 2017 Atlantic hurricane season impact on communications-Report and recommendations: Public Safety and Homeland Security Bureau, Public Safety Docket no. 17-344, accessed December 17, 2018, at https://docs.fcc.gov/public/ attachments/DOC-353805A1.pdf.

Federal Emergency Management Agency, 2016a, Coastal flood risks - Achieving resilience together website, accessed December 19, 2016, at https://www.fema.gov/ coastal-flood-risks-achieving-resilience-together.

Federal Emergency Management Agency, 2016b, FEMA flood map service center-Hazus: Federal Emergency Management Agency, accessed December 19, 2016, at https://msc.fema.gov/portal/resources/hazus.
Federal Emergency Management Agency, 2018, Hazus multi-hazard loss estimation methodology, flood model, Hazus ${ }^{\circledR}-\mathrm{MH}$ MR3 technical manual, 471 p., accessed February 22, 2018, at https://www.fema. gov/plan/prevent/hazus. [Document moved by time of publication; accessed March 5, 2019, at https://www.hsdl. org/?abstract\&did=480580.]

Ferrario, F., Beck, M.W., Storlazzi, C.D., Micheli, F., Shepard, C.C., and Airoldi, L., 2014, The effectiveness of coral reefs for coastal hazard risk reduction and adaptation: Nature Communications, v. 5, 9 p.

Florida Fish and Wildlife Conservation Commission, 2016, Unified Florida Coral Reef Tract Map Version 2.0: Fish and Wildlife Research Institute, accessed September 17, 2017, at http://ocean.floridamarine.org/IntegratedReefMap/ UnifiedReefTract.htm.

Fox, H.E., Mous, P.J., Pet, J.S., Muljadi, A.H., and Caldwell, R.L., 2005, Experimental assessment of coral reef rehabilitation following blast fishing: Conservation Biology, v. 19, p. 98-107.

Gardner, T.A., Cote, I.M., Gill, J.A., Grant, A., and Watkinson, A.R., 2005, Hurricanes and Caribbean coral reefs-Impacts, recovery patterns, and role in long-term decline: Ecology, v. 86, p. $174-184$.

Grinsted, A., Moore, J.C., and Jevrejeva, S., 2010, Reconstructing sea level from paleo and projected temperatures 200 to 2100 AD: Climate Dynamics, v. 34, p. 461-472.

Grothe, P.R., Taylor, L.A., Eakins, B.W., Carignan, K.S., Friday, D.Z., Lim, E., and Love, M.R., 2011, Key West, Florida 1/3 arc-second MHW coastal digital elevation model: National Oceanic and Atmospheric Administration, accessed on March 9, 2021, at https://data.noaa.gov// metaview/page?xml=NOAA/NESDIS/NGDC/MGG/DEM/ iso/xml/431.xml\&view=getDataView\&header=none.

Haisfield, K.M., Fox, H.E., Yen, S., Mangubhai, S., and Mous, P.J., 2010, An ounce of prevention-Cost-effectiveness of coral reef rehabilitation relative to enforcement: Conservation Letters, v. 3, p. 243-250.

Hallegatte, S., Green, C., Nicholls, R.J., and Corfee-Morlot, J., 2013, Future flood losses in major coastal cities: Nature Climate Change, v. 3, p. 802-806.

Heron, S., Morgan, J., Eakin, C.M., and Skirving, W., 2008, Hurricanes and their effects on coral reefs, in Wilkinson, C., and Souter, D., Status of Caribbean coral reefs after bleaching and hurricanes in 2005: Global Coral Reef Monitoring Network, Reef and Rainforest Research Centre, p. 31-36.

Hinkel, J., Lincke, D., Vafeidis, A.T., Perrette, M., Nicholls, R.J., Tol, R.S.J., Marzeion, B., Fettweis, X., Ionescu, C., and Levermann, A., 2014, Coastal flood damage and adaptation costs under 21 st century sea-level rise: Proceedings of the National Academy of Sciences, v. 111, no. 9, p. 3292-3297. 
Hoeke, R.K., Storlazzi, C.D., and Ridd, P.V., 2011, Hydrodynamics of a bathymetrically complex fringing coral reef embayment-Wave climate, in situ observations, and wave prediction: Journal of Geophysical Research Oceans, v. 166, $19 \mathrm{p}$.

Kopp, R.E., Horton, R.M., Little, C.M., Mitrovica, J.X., Oppenheimer, M., Rasmussen, D.J., Strauss, B.H., and Tebaldi, C., 2014, Probabilistic 21st and 22nd century sealevel projections at a global network of tide-gauge sites: Earth's Future, v. 2, p. 383-406.

Lugo, A.E., Rogers, C.S., and Nixon, S.W., 2000, Hurricanes, coral reefs and rainforests-Resistance, ruin and recovery in the Caribbean: AMBIO-A Journal of the Human Environment, v. 29, p. 106-115.

McCreless, E., and Beck, M.W., 2016, Rethinking our global coastal investment portfolio: Journal of Ocean and Coastal Economics, v. 3, no. 6, 19 p.

Méndez, F.J., Menéndez, M., Luceño, A., and Losada, I.J., 2006, Estimation of the long-term variability of extreme significant wave height using a time-dependent Peak Over Threshold (POT) model: Journal of Geophysical Research Oceans, v. 111, 13 p.

Menéndez, M., and Woodworth, P.L., 2010, Changes in extreme high water levels based on a quasi-global tidegauge data set: Journal of Geophysical Research Oceans, v. 115,15 p.

Frost, E., and Bove, M., 2017, The hurricane season of 2017-A cluster of extreme storms: Munich Re webpage, accessed March 9, 2021, at https://www.munichre.com/ topics-online/en/climate-change-and-natural-disasters/ natural-disasters/storms/hurricane-season-2017.html.

Montoya-Maya, P.H., Smit, K.P., Burt, A.J., and Frias-Torres, S., 2016, Large-scale coral reef restoration could assist natural recovery in Seychelles, Indian Ocean: Nature Conservation, v. 16, p. 1-17.

National Geophysical Data Center, 2001, U.S. coastal relief model-Florida and east Gulf of Mexico: National Oceanic and Atmospheric Administration National Geophysical Data Center, accessed December 19, 2016, at https://doi. org/10.7289/V5W66HPP.

National Oceanic and Atmospheric Administration, 2001, Benthic habitats of Puerto Rico: National Oceanic and Atmospheric Administration Coastal Services Center, accessed September 17, 2017, at https://products. coastalscience.noaa.gov/collections/benthic/e95usvi_pr/ default.aspx.

National Oceanic and Atmospheric Administration, 2015, Electronic navigational charts: National Oceanic and Atmospheric Administration Office of Coast Survey, accessed March 10, 2021, at https://www.nauticalcharts. noaa.gov/charts/noaa-enc.html.
National Oceanic and Atmospheric Administration, 2017, Extreme water levels-Annual exceedance probability curves, accessed December 19, 2016, at https://

tidesandcurrents.noaa.gov/est/.

National Research Council, 2014, Reducing coastal risks on the East and Gulf Coasts: The National Academies Press, Washington, D.C., 208 p., https://doi.org/10.17226/18811.

National Science and Technology Council, 2015, Ecosystemservice assessment- - Research needs for coastal green infrastructure: Office of Science and Technology Policy, $40 \mathrm{p}$.

Neumann, B., Vafeidis, A.T., Zimmermann, J., and Nicholls, R.J., 2015, Future coastal population growth and exposure to sea-level rise and coastal flooding - A global assessment: PLOS ONE, v. 10, no. 3, 34 p., https://doi.org/10.1371/ journal.pone.0118571.

Olsen, A.S., Zhou, Q., Linde, J.J., and Arnbjerg-Nielsen, K., 2015, Comparing methods of calculating expected annual damage in urban pluvial flood risk assessments: Water, v. 7, p. 255-270.

Pasch, R.J., Penny, A.B., and Berg, R., 2018, Tropical cyclone report-Hurricane Maria: National Hurricane Center, 48 p., accessed December 17, 2018, at https://www.nhc.noaa.gov/ data/tcr/AL152017_Maria.pdf.

Pomeroy, A., Lowe, R.J., Symonds, G., van Dongeren, A.R., and Moore, C., 2012, The dynamics of infragravity wave transformation over a fringing reef: Journal of Geophysical Research, v. 117, 17 p.

Quataert, E., Storlazzi, C.D., van Rooijen, A., Cheriton, O.M., and van Dongeren, A.R., 2015, The influence of coral reefs and climate change on wave-driven flooding of tropical coastlines: Geophysical Research Letters, v. 42, no. 15, p. 6407-6415.

Reguero, B.G., Beck, M.W., Agostini, V.N., Kramer, P., and Hancock, B., 2018, Coral reefs for coastal protection-A new methodological approach and engineering case study in Grenada: Journal of Environmental Management, v. 210, p. $146-161$.

Reguero, B.G., Menéndez, M., Méndez, F.J., Mínguez, R., and Losada, I.J., 2012, A global ocean wave (GOW) calibrated reanalysis from 1948 onwards: Coastal Engineering, v. 65, p. $38-55$.

Rinkevich, B., 2015, Climate change and active reef restoration-Ways of constructing the "reefs of tomorrow": Journal of Marine Science and Engineering, v. 3, p. 111-127.

Ris, R.C., Holthuijsen, L.H., and Booij, N., 1999, A thirdgeneration wave model for coastal regions-Part 2. Verification: Journal of Geophysical Research Oceans, v. 104 , no. C4, p. 7667-7681. 
Roelvink, D., Reniers, A., van Dongeren, A.R., van Thiel de Vries, J., McCall, R. and Lescinski, J., 2009, Modelling storm impacts on beaches, dunes and barrier islands: Coastal Engineering, v. 56, p. 1133-1152.

Rogers, C.S., 1993, Hurricanes and coral reefs-The intermediate disturbance hypothesis revisited: Coral Reef, v. 12 , p. $127-137$.

Scawthorn, C., Blais, N., Seligson, H., Tate, E., Mifflin, E., Thomas, W., Murphy, J., and Jones, C., 2006a, HAZUS-MH flood loss estimation methodology I-Overview and flood hazard characterization: Natural Hazards Review, v. 7 , p. 60-71.

Scawthorn, C., Flores, P., Blais, N., Seligson, H., Tate, E., Chang, S., Mifflin, E., Thomas, W., Murphy, J., Jones, C., and Lawrence, M., 2006b, HAZUS-MH flood loss estimation methodology II—Damage and loss assessment: Natural Hazards Review, v. 7, p. 72-81.

Scoffin, T.P., 1993, The geological effects of hurricanes on coral reefs and the interpretation of storm deposits: Coral Reefs, v. 12, p. 203-221.

Scott, F., Antolinez, J., McCall, R., Storlazzi, C., Reniers, A., and Pearson, S., 2020, Hydro-morphological characterization of coral reefs for wave-runup prediction: Frontiers in Marine Science, v. 7, 20 p., https://doi. org/10.3389/fmars.2020.00361.

Sheppard, C., Dixon, D.J., Gourlay, M., Sheppard, A., and Payet, R., 2005, Coral mortality increases wave energy reaching shores protected by reef flats-Examples from the Seychelles: Estuarine, Coastal and Shelf Science, v. 64, p. 223-234.

Storlazzi, C.D., Elias, E.P.L., and Berkowitz, P., 2015, Many atolls may be uninhabitable within decades due to climate change: Scientific Reports, v. 5, no. 14546, 9 p.

Storlazzi, C.D., Gingerich, S.B., van Dongeren, A.R., Cheriton, O.M., Swarzenski, P.W., Quataert, E., Voss, C.I., Field D.W., Annamalai, H., Piniak G.A., and McCall, R., 2018, Most atolls will be uninhabitable by the mid-21st century because of sea-level rise exacerbating wave-driven flooding: Science Advances, v. 4, https://doi.org/10.1126/ sciadv.aap9741.

Storlazzi, C.D., Reguero, B.G., Cole, A.D., Lowe, E., Shope, J.B., Gibbs, A.E., Nickel, B.A., McCall, R.T., van Dongeren, A.R., and Beck, M.W., 2019, Rigorously valuing the role of U.S. coral reefs in coastal hazard risk reduction: U.S. Geological Survey Open-File Report 2019-1027, 42 p., https://doi.org/10.3133/ofr20191027.

Taebi, S., and Pattiaratchi, C., 2014, Hydrodynamic response of a fringing coral reef to a rise in mean sea level: Ocean Dynamics, v. 64, no. 7, p. 975-987.
Taylor, L.A., Eakins, B.W., Carignan, K.S., Warnken, R.R., Sazonova, T., and Schoolcraft, D.C., 2008a, Puerto Rico coastal digital elevation model: National Oceanic and Atmospheric Administration Technical Memorandum NESDIS NGDC-13, accessed December 19, 2016, at https://www.ngdc.noaa.gov/dem/squareCellGrid/ download/1561. [Data moved by time of publication; accessed March 4, 2019, at https://data.noaa.gov//metaview/ page?xml=NOAA/NESDIS/NGDC/MGG/DEM/iso/ $\mathrm{xml} / 1561 . \mathrm{xml} \& \mathrm{view}=$ getDataView\&header=none.]

Taylor, L.A., Eakins, B.W., Carignan, K.S., Warnken, R.R., Sazonova, T., and Schoolcraft, D.C., 2008b, Arecibo, Puerto Rico coastal digital elevation model: National Oceanic and Atmospheric Administration Technical Memorandum NESDIS NGDC-13, accessed December 19, 2016, at https://www.ngdc.noaa.gov/dem/squareCellGrid/ download/393. [Data moved by time of publication; accessed March 4, 2019, at https://data.noaa.gov//metaview/ page?xml=NOAA/NESDIS/NGDC/MGG/DEM/iso/ $\mathrm{xml} / 393 . \mathrm{xml} \& \mathrm{view}=$ getDataView\&header=none.]

Taylor, L.A., Eakins, B.W., Carignan, K.S., Warnken, R.R., Sazonova, T., and Schoolcraft, D.C., 2008c, Fajardo, Puerto Rico 1/3 arc-second MHW coastal digital elevation model: National Oceanic and Atmospheric Administration Technical Memorandum NESDIS NGDC-13, accessed December 19, 2016 at https://www.ngdc.noaa.gov/dem/ squareCellGrid/download/689. [Data moved by time of publication; accessed March 5, 2019, at https://data.noaa. gov//metaview/page?xml=NOAA/NESDIS/NGDC/MGG/ DEM/iso/xml/689.xml\&view=getDataView\&header=none.]

Taylor, L.A., Eakins, B.W., Carignan, K.S., Warnken, R.R., Sazonova, T., and Schoolcraft, D.C., 2008d, Guayama, Puerto Rico 1/3 arc-second MHW coastal digital elevation model: National Oceanic and Atmospheric Administration Technical Memorandum NESDIS NGDC-13, accessed December 19, 2016, at https://www.ngdc.noaa.gov/dem/ squareCellGrid/download/691. [Data moved by time of publication; accessed March 5, 2019, at https://data.noaa. gov//metaview/page?xml=NOAA/NESDIS/NGDC/MGG/ $\mathrm{DEM} / \mathrm{iso} / \mathrm{xml} / 691 . \mathrm{xml} \& \mathrm{view}=\mathrm{getDataView} \&$ header=none.]

Taylor, L.A., Eakins, B.W., Carignan, K.S., Warnken, R.R., Sazonova, T., and Schoolcraft, D.C., 2008e, Mayaguez, Puerto Rico 1/3 arc-second MHW coastal digital elevation model 2007: National Oceanic and Atmospheric Administration Technical Memorandum NESDIS NGDC13, accessed December 19, 2016, at https://www.ngdc.noaa. gov/dem/squareCellGrid/download/1541. [Data moved by time of publication; accessed March 5, 2019, at https://data. noaa.gov//metaview/page?xml=NOAA/NESDIS/NGDC/ MGG/DEM/iso/xml/1541.xml\&view=getDataView\&heade $\mathrm{r}=$ none.] 
Taylor, L.A., Eakins, B.W., Carignan, K.S., Warnken, R.R., Sazonova, T., and Schoolcraft, D.C., 2008f, Ponce, Puerto Rico 1/3 arc-second MHW coastal digital elevation model: National Oceanic and Atmospheric Administration Technical Memorandum NESDIS NGDC-13, accessed December 19, 2016, at https:/www.ngdc.noaa.gov/dem/ squareCellGrid/download/391. [Data moved by time of publication; accessed March 5, 2019, at https:/data.noaa. gov//metaview/page?xml=NOAA/NESDIS/NGDC/MGG/ $\mathrm{DEM} /$ iso/xml/391.xml\&view=getDataView\&header=none.]

Taylor, L.A., Eakins, B.W., Carignan, K.S., Warnken, R.R., Sazonova, T., and Schoolcraft, D.C., 2008g, San Juan, Puerto Rico coastal digital elevation model: National Oceanic and Atmospheric Administration Technical Memorandum NESDIS NGDC-13, accessed December 19, 2016, at https://www.ngdc.noaa.gov/dem/squareCellGrid/ download/1601. [Data moved by time of publication; accessed March 5, 2019, at https://data.noaa.gov//metaview/ page?xml=NOAA/NESDIS/NGDC/MGG/DEM/iso/ $\mathrm{xml} / 1601 . \mathrm{xml} \& \mathrm{view}=$ getDataView\&header=none.]

Thieler, E.R., Himmelstoss, E.A., Zichichi, J.L., and Ergul, A., 2009, The Digital Shoreline Analysis System (DSAS) version 4.0 - An ArcGIS extension for calculating shoreline change: U.S. Geological Survey Open-File Report 20081278, https://doi.org/10.3133/ofr20081278.

United Nations, 2016, World population prospects 2016 database, accessed December 19, 2016, at https://esa.un.org/ unpd/wpp/.

United Nations Office for Disaster Risk Reduction, 2011, Global assessment report on disaster risk reductionRevealing risk, redefining development: United Nations, Oxford, U.K., 178 p.

U.S. Census Bureau, 2016, TIGER products database, accessed December 19, 2016, at https:/www.census.gov/ geo/maps-data/data/tiger.html.

U.S. Census Bureau, 2018, 2010 Statistics of U.S. businesses (SUSB) annual datasets by establishment industry: U.S. Census Bureau online database, accessed February 22, 2018, at https:/www.census.gov/data/tables/2010/econ/ susb/2010-susb-annual.html.

van Dongeren, A.R., Lowe, R.J., Pomeroy, A., Trang, D.M., Roelvink, D., Symonds, G., and Ranasinghe, R., 2013, Numerical modeling of low-frequency wave dynamics over a fringing coral reef: Coastal Engineering, v. 73, p. 178-190.

van Zanten, B.T., van Beukering, P.J.H., and Wagtendonk, A.J., 2014, Coastal protection by coral reefs-A framework for spatial assessment and economic valuation: Ocean and Coastal Management, v. 96, p. 94-103.
Viehman, T.S., Buckel, C., Griffin, S., Groves, S., Nemeth, M., Moore, J., and Moore, T., 2020a, NCCOS AssessmentAssessment of Puerto Rico's coral reefs following Hurricanes Irma and Maria from 2018-02-25 to 201806-15 (NCEI Accession 0221189): National Oceanic and Atmospheric Administration National Centers for Environmental Information Dataset, accessed March 3, 2020, at https://doi.org/10.25921/a1c4-bg06.

Viehman, T.S., Gittings, S., Groves, S., Moore, J., Moore, T., and Stein, J., 2018, NCCOS Assessment-Coral Disturbance Response Monitoring (DRM) along the Florida reef tract following Hurricane Irma from 2017-10-09 to 2017-10-18 (NCEI Accession 0179071): National Oceanic and Atmospheric Administration National Centers for Environmental Information Dataset, accessed March 3, 2020, at https://doi.org/10.25921/sscd-6h41.

Viehman, T.S., Nemeth, M., Groves, S., Buckel, C., Griffin, S., Moore, T., and Moore, J., 2020b, Coral assessment and restoration in the U.S. Caribbean after 2017 hurricanes: National Oceanic and Atmospheric Administration National Ocean Service, National Centers for Coastal Ocean Science Technical Memorandum 278, accessed March 3, 2020, at https://doi.org/10.25923/7r0b-wc52.

Vermeer, M., and Rahmstorf, S., 2009, Global sea level linked to global temperature: Proceedings of the National Academy of Sciences, v. 106, no. 51, p. 21,527-21,532.

Wood, N.J., Ratliff, J., and Peters, J., 2013, Community exposure to tsunami hazards in California: U.S. Geological Survey Scientific Investigations Report 2012-5222, 49 p.

Zitello, A.G., Bauer, L.J., Battista, T.A., Mueller, P.W., and Kendall, M.S., 2009, Benthic habitats of St. John, U.S. Virgin Islands: National Oceanic and Atmospheric Administration Technical Memorandum NOS NCCOS 96, accessed September 17, 2017, at https://products. coastalscience.noaa.gov/collections/benthic/e94stjohn/ default.aspx.

\section{Additional Digital Information}

The digital data used to produce this report can be found here: https://doi.org/10.5066/P9EHOBKO

For an online portable document format (PDF) version of this report, visit https://doi.org/10.3133/ofr20211056

For more information on the U.S. Geological Survey's Coral Reef Project, visit http://coralreefs.wr.usgs.gov/

For more information on the U.S. Geological Survey Coastal and Marine Program's Coastal Change Hazards portal, visit https://marine.usgs.gov/coastalchangehazardsportal/ 
For more information on the University of California at Santa Cruz's Coastal Resilience Laboratory, visit https://coastalresilience.ucsc.edu/

For more information on the University of California at Santa Cruz's Center for Integrated Spatial Research, visit: http://spatial.cisr.ucsc.edu/

For more information on NOAA National Centers for Coastal Ocean Science, visit https://coastalscience.noaa.gov/

\section{Direct Contact Information}

Regarding this report, contact Curt D. Storlazzi (USGS Coral Reef Project Chief) at cstorlazzi@usgs.gov 
Appendixes 1-6 


\section{Appendix 1. SWAN Model Settings}

\begin{tabular}{|c|c|}
\hline Parameter & Value \\
\hline \multicolumn{2}{|c|}{ General } \\
\hline OnlyInputVerify & false \\
\hline SimMode & stationary \\
\hline DirConvention & nautical \\
\hline WindSpeed & $0.0000000 \mathrm{e}+000$ \\
\hline WindDir & $0.0000000 \mathrm{e}+000$ \\
\hline \multicolumn{2}{|c|}{ Processes } \\
\hline GenModePhys & 3 \\
\hline Breaking & true \\
\hline BreakAlpha & $1.0000000 \mathrm{e}+000$ \\
\hline BreakGamma & $7.3000002 \mathrm{e}-001$ \\
\hline Triads & false \\
\hline TriadsAlpha & $1.0000000 \mathrm{e}-001$ \\
\hline TriadsBeta & $2.2000000 \mathrm{e}+000$ \\
\hline WaveSetup & false \\
\hline BedFriction & jonswap \\
\hline BedFricCoef & $6.7000002 \mathrm{e}-002$ \\
\hline Diffraction & true \\
\hline DiffracCoef & $2.0000000 \mathrm{e}-001$ \\
\hline DiffracSteps & 5 \\
\hline DiffracProp & true \\
\hline WindGrowth & false \\
\hline WhiteCapping & Komen \\
\hline Quadruplets & false \\
\hline Refraction & true \\
\hline FreqShift & true \\
\hline WaveForces & dissipation $3 \mathrm{~d}$ \\
\hline \multicolumn{2}{|c|}{ Numerics } \\
\hline DirSpaceCDD & $5.0000000 \mathrm{e}-001$ \\
\hline
\end{tabular}

\begin{tabular}{|c|c|}
\hline Parameter & Value \\
\hline FreqSpaceCSS & $5.0000000 \mathrm{e}-001$ \\
\hline RChHsTm01 & $2.0000000 \mathrm{e}-002$ \\
\hline RChMeanHs & $2.0000000 \mathrm{e}-002$ \\
\hline RChMeanTm01 & $2.0000000 \mathrm{e}-002$ \\
\hline PercWet & $9.8000000 \mathrm{e}+001$ \\
\hline MaxIter & 100 \\
\hline \multicolumn{2}{|c|}{ Output } \\
\hline TestOutputLevel & 0 \\
\hline TraceCalls & false \\
\hline UseHotFile & false \\
\hline WriteCOM & false \\
\hline \multicolumn{2}{|c|}{ Domain } \\
\hline DirSpace & circle \\
\hline NDir & 72 \\
\hline StartDir & $0.0000000 \mathrm{e}+000$ \\
\hline EndDir & $0.0000000 \mathrm{e}+000$ \\
\hline FreqMin & $5.0000001 \mathrm{e}-002$ \\
\hline FreqMax & $1.0000000 \mathrm{e}+000$ \\
\hline NFreq & 24 \\
\hline Output & true \\
\hline \multicolumn{2}{|c|}{ Boundary } \\
\hline Definition & orientation \\
\hline SpectrumSpec & parametric \\
\hline SpShapeType & jonswap \\
\hline PeriodType & peak \\
\hline DirSpreadType & power \\
\hline PeakEnhanceFac & $=3.3000000 \mathrm{e}+000$ \\
\hline GaussSpread & $9.9999998 \mathrm{e}-003$ \\
\hline
\end{tabular}




\section{Appendix 2. SWAN Model Grid Information}

[km, kilometer; m, meter; NGDC, National Geophysical Data Center; PR, Puerto Rico, - , no data]

\begin{tabular}{|c|c|c|c|c|}
\hline Location & 1-km grid cells & 200-m grid cells & Grid dimensions (E-W x N-S) & Data source \\
\hline Florida & - & Dry Tortugas & $295 \times 190$ & NGDC, 2001 \\
\hline Florida & - & Key West & $505 \times 255$ & NGDC, 2001 \\
\hline Florida & - & Islamorada & $383 \times 334$ & NGDC, 2001 \\
\hline Florida & - & Miami & $291 \times 502$ & NGDC, 2001 \\
\hline Puerto Rico & - & PR_North-Central & $330 \times 155$ & Taylor and others, $2008 \mathrm{a}$ \\
\hline Puerto Rico & - & PR_Northeast & $330 \times 155$ & Taylor and others, 2008a \\
\hline Puerto Rico & - & PR_Northwest & $315 \times 155$ & Taylor and others, 2008a \\
\hline Puerto Rico & - & PR_South-Central & $320 \times 160$ & Taylor and others, 2008a \\
\hline
\end{tabular}

\section{Appendix 3. Benthic Habitat and Shoreline Datasets}

[FFWCC, Florida Fish and Wildlife Conservation Commission; NOAA, National Oceanic and Atmospheric Administration]

\begin{tabular}{|c|c|c|c|c|}
\hline \multirow{2}{*}{ Location } & \multirow{2}{*}{ Sublocation } & \multicolumn{2}{|c|}{ Benthic habitat data } & \multirow{2}{*}{ Shoreline data source } \\
\hline & & Minimum mapping unit & Data source & \\
\hline Florida & Dry Tortugas & $<1$ acre & FFWCC, 2016 & NOAA, 2015 \\
\hline Florida & Keys & $<1$ acre & FFWCC, 2016 & NOAA, 2015 \\
\hline Florida & Miami & $<1$ acre & FFWCC, 2016 & NOAA, 2015 \\
\hline Puerto Rico & Puerto Rico & 1 acre & NOAA, 2001 & NOAA, 2015 \\
\hline Puerto Rico & Culebra & 1 acre & NOAA, 2001 & NOAA, 2015 \\
\hline Puerto Rico & Vieques & 1 acre & NOAA, 2001 & NOAA, 2015 \\
\hline
\end{tabular}




\section{Appendix 4. Cross-shore XBeach Transects}

\begin{tabular}{llc}
\hline \multicolumn{1}{c}{ Location } & \multicolumn{1}{c}{ Sublocation } & Number of cross-shore transects \\
\hline Florida & Dry Tortugas & 300 \\
Florida & Key West & 545 \\
Florida & Keys & 1,127 \\
Florida & Miami & 1,139 \\
Florida & Palm Beach & 1,168 \\
Puerto Rico & Puerto Rico & 4,588 \\
Puerto Rico & Culebra & 244 \\
Puerto Rico & Vieques & 687 \\
\hline
\end{tabular}

\section{Appendix 5. Bathymetric Datasets}

[NGDC, National Geophysical Data Center]

\begin{tabular}{lll}
\hline \multicolumn{1}{c}{ Location } & \multicolumn{1}{c}{ Sublocation } & \multicolumn{1}{c}{ Data source } \\
\hline Florida & Dry Tortugas & NGDC, 2001 \\
Florida & Key West & Grothe and others, 2011 \\
Florida & Florida Keys & NGDC, 2001 \\
Florida & Miami & Carignan and others, 2015 \\
Florida & Palm Beach & NGDC, 2001 \\
Puerto Rico & Arecibo & Taylor and others, 2008b \\
Puerto Rico & Culebra & Taylor and others, 2008a \\
Puerto Rico & Fajardo & Taylor and others, 2008c \\
Puerto Rico & Guayama & Taylor and others, 2008d \\
Puerto Rico & Mayaguez & Taylor and others, 2008e \\
Puerto Rico & Ponce & Taylor and others, 2008f \\
Puerto Rico & San Juan & Taylor and others, 2008g \\
Puerto Rico & Vieques & Taylor and others, 2008a \\
\hline
\end{tabular}




\section{Appendix 6. XBeach Model Settings}

$[-$, no data $]$

\begin{tabular}{|c|c|c|}
\hline Category & Parameter & Value \\
\hline \multirow[t]{4}{*}{ Flow boundary condition parameters } & front & abs_1d \\
\hline & left & wall \\
\hline & right & wall \\
\hline & back & wall \\
\hline \multirow[t]{2}{*}{ Flow } & bedfriction & chezy \\
\hline & bedfricfile & fric.txt \\
\hline \multirow[t]{3}{*}{ Grid parameters } & thetamin & -60 \\
\hline & thetamax & 60 \\
\hline & dtheta & 10 \\
\hline Model time & tstop & 3,600 \\
\hline Tide boundary conditions & tideloc & 1 \\
\hline \multirow[t]{2}{*}{ Wave boundary condition parameters } & instat & jons \\
\hline & $\operatorname{dir} 0$ & 270 \\
\hline \multirow[t]{6}{*}{ Output variables } & outputformat & netcdf \\
\hline & rugdepth & 0.020000 \\
\hline & tintm & 3,500 \\
\hline & tintp & 10 \\
\hline & tintg & 3,100 \\
\hline & tstart & 100 \\
\hline \multirow[t]{11}{*}{ Output options } & nglobalvar & 4 \\
\hline & $\mathrm{H}$ & - \\
\hline & zs & - \\
\hline & $\mathrm{zb}$ & - \\
\hline & $\mathrm{E}$ & - \\
\hline & nmeanvar & 3 \\
\hline & $\mathrm{H}$ & - \\
\hline & zs & - \\
\hline & $\mathrm{zb}$ & - \\
\hline & npoints & 1 \\
\hline & nrugauge & 1 \\
\hline
\end{tabular}


Moffett Field Publishing Service Center, California Manuscript approved for publication May 6, 2021 Edited by John Mark Brigham

Layout and design by Kimber Petersen

Cartography and illustration support by JoJo Mangano 
